\title{
A 100-Year Review: Calf nutrition and management ${ }^{1}$
}

\author{
A. F. Kertz, ${ }^{2}$ T. M. Hill,† J. D. Quigley III,† A. J. Heinrichs,ł J. G. Linn,§ and J. K. Drackley\# \\ ${ }^{*}$ Andhil LLC, St. Louis, MO 63122 \\ †Provimi North America, Brookville, OH 45309 \\ ‡Department of Dairy and Animal Science, Pennsylvania State University, University Park 16802 \\ §Department of Animal Science, University of Minnesota, White Bear Lake 55110-5767 \\ \#Department of Animal Sciences, University of Illinois, Urbana 61801-4733
}

\section{ABSTRACT}

The first calf paper, published in the May 1919 issue of the Journal of Dairy Science (JDS), described factors affecting birth body weight of different breeds of calves. Other studies were done on nonmilk ingredients, growth charts were developed, and early weaning was followed to conserve milk fed to calves. Calf papers did not report use of statistics to control or record variation or to determine whether treatment means were different. Many experiments were more observational than comparative. Typically fewer than 5 calves, and sometimes 1 or 2 calves, were used per treatment. During the next $20 \mathrm{yr}$, calf studies increased and included colostrum feeding, milk and milk replacer feeding, minerals and vitamins, and fats and oils. Many concepts fundamental to current knowledge and understanding of digestion, rumen development, and milk replacer formulation were developed during this period. In addition, the concept of using antibiotic growth promoters in dairy calf diets was first evaluated and developed during the 1950s. During the 20-yr period of January 1957 through December 1976, a large number of universities in the United States and 1 in Canada contributed almost 150 papers on a variety of calf-related topics. These topics included genetics, physiology of the calf, review of calf immunity, antibiotic feeding, and milk replacer ingredients. This became the golden era of calf rumen development studies, which also engendered studies of calf starter rations and ingredients. A classic review of management, feeding, and housing studies summarized research related to calf feeding and management systems up to that point with an emphasis on maintaining calf growth and health while reducing

\footnotetext{
Received April 21, 2017.

Accepted August 2, 2017.

${ }^{1}$ This review is part of a special issue of the Journal of Dairy Science commissioned to celebrate 100 years of publishing (1917-2017).

${ }^{2}$ Corresponding author: andhil@swbell.net
}

labor and feed costs. It was also during this period that metric measurements replaced English units. In the 20yr period from 1977 to 1996, more than 400 articles on calf nutrition and management were published in JDS. With the growing research interest in calves, a paper outlining standardized procedures for conducting and reporting data from calf experiments was first published. A very active area of calf nutrition research from the late 1970s to the mid 1980s was colostrum quality, feeding, and preservation; more than 60 such research articles were published in the journal during this time. Various nonmilk protein sources were evaluated. Extensive studies were done evaluating trace and major mineral requirements in calves along with some vitamin studies. Throughout the 1970s, 1980s, and 1990s, the primary objective of most calf research was how to wean healthy, adequately grown calves at an early age - generally less than $30 \mathrm{~d}$ of age. This program was reviewed in a 1979 publication. Research on calf starter ingredients, nutrient composition, and additives was minimal in the 1980s and 1990s given the importance of starter intake to the success of early weaning, but the role of water intake in starter intake and growth was established. Research on issues with calves continued to increase during the last 20-yr period as evidenced by publication of more than 580 articles in JDS as well as many more in other refereed journals. In addition to papers contributed by several universities in the United States and Canada, the number of papers authored by scientists at universities and institutes in other countries increased dramatically during this period. Factors influencing colostral antibody absorption, heat treatment of colostrum, and efficacy of colostrum supplements and replacers were reported. Most studies in this period related to nutrition. Studies were published supporting greater neonatal growth rates from feeding more milk replacer but with a higher crude protein content than traditional. Protein energy effects on growth and body composition were evaluated in concert with greater growth rates. Milk and nonmilk protein sources in milk replacers along with AA supplementation were evalu- 
ated. Limited studies were done with fat sources and fatty acid supplementation along with trace minerals and fat-soluble vitamins. Waste milk feeding and heat treatment became more prevalent. Studies established starter ingredient palatability and use of forage when fed with pelleted starters. With the advent of automatic milk and milk replacer feeders, factors influencing how and when to wean were established. Research programs established factors affecting calf behavior and welfare. Several databases were evaluated along with various published studies, and established calf growth during the first 2 mo was subsequently reflected in first- and later-lactation milk production of those calves. A new area of calf research that emerged from 1997 on was the effects of maternal environment and nutrition on calf health, growth, and future productivity. From a mechanistic standpoint, the field of epigenetics seems likely to explain many of these phenomena. Some possibilities for future calf nutrition and management were elaborated.

Key words: calf, nutrition, management, growth

\section{INTRODUCTION}

When dairy calves are born they have no innate immunity, nor are they functioning ruminants. They face the 2 major challenges of acquiring immunity and initially feeding as a nonruminant while rumen development and function are established. A calf depends on colostrum from its dam to initially acquire immunity through absorption of antibodies before it later begins to synthesize its own antibodies. A calf's liquid diet provides the majority of nutrition until the calf begins to consume enough dry diet, which will contribute to development of its rumen and allow it to be weaned from the liquid diet. Meeting these challenges involves myriad nutrition and management practices that have been researched over the past $100 \mathrm{yr}$ and that have largely been published in the Journal of Dairy Science (JDS) by the American Dairy Science Association. In 1906, the USDA estimated that there were about 18 million dairy cows in the United States, with an average of about 4 cows on 15 million dairy farms (Jones, 2006). In 2015, there were 9.317 million dairy cows in the United States (USDA, 2016), with an average of about 214 cows on 43,584 commercial dairy herds (Olson, 2016). As the number of cows per herd increased over the past $100+\mathrm{yr}$, feeding and management practices have changed (see Appendix Table A1). Newer nutrition and management information generated by scientific studies with calves has increasingly been adopted. This review succinctly addresses key studies in 20-yr segments.

\section{TO 1936}

During the first $20 \mathrm{yr}$ of the journal, 16 different research units contributed papers on various topics in calf nutrition, management, and growth. C. H. Eckles of the University of Missouri published the first paper on calves in the May 1919 issue using records of 654 animals describing birth BW of calves of different breeds (Eckles, 1919). Birth BW of first-, second-, ninth-, and tenth-parity dams was less than birth BW of third- through eighth-parity dams. Males were 5 to $8 \%$ heavier than females. Length of gestation was not related to birth BW. Using a subset of 29 cows fed low or high levels of nutrients, Eckles reported that nutrition of the dam did not affect calf birth BW. Eckles moved to the University of Minnesota and in the first $20 \mathrm{yr}$ of the journal published 7 other papers on topics of milk substitutes, feeding yeast, calves not requiring sunlight (vitamins were supplemented), vitamin A being required, and vitamin $\mathrm{C}$ and $\mathrm{B}$ vitamins not being required.

In the July 1919 issue, R. E. Caldwell from Purdue University stated in his introduction that $19 \%$ of nutrients consumed by Americans came from milk and milk products (Caldwell, 1919). Additionally, he wrote of the need for food conservation in the years after World War I and thus the need to reduce milk fed to calves. He evaluated liquid and dried blood and boiled clover juice as milk substitutes using both $\mathrm{N}$ balance studies and measurements of BW gain in 4 calves. They were not adequate replacements for milk.

In the November 1919 issue, W. B. Nevens from the University of Nebraska evaluated the use of self-feeders for grain mixes fed to 5 calves (Nevens, 1919). Selffeeders were used for other farm animals, and ways to conserve labor were needed because dairy farm laborers were scarce. Self-feeders were satisfactory.

In the first $20 \mathrm{yr}$ of the journal, A. C. McCandlish from Iowa State College was the most prolific author of calf papers, with 9 articles on calves plus many more on other topics. His first article, in May 1922, was based on 369 gestations over 14 yr (McCandlish, 1922a). He reported that calves born in winter were heavier than calves born in summer. Also, hip width growth was greater than height growth when expressed as percentage change. Growth charts to calving were first reported in the journal in May 1922 (McCandlish, 1922b). He described construction of a metabolism crate for calves (McCandlish and Ely, 1922). He reported in the September and November 1923 issues that calves prefer whole corn and whole oats to ground grains but that older, weaned calves preferred ground grains (McCandlish, 1923a,b). He also evaluated self-feeders for dry feeds and several other topics. In the introduction to 
his paper in the July 1922 issue, McCandlish (1922b) wrote, "Many calves are improperly fed from birth, while in an even larger number of cases the calves are reared well until weaning then when they are turned loose to rustle for themselves." This situation is still prevalent in the industry today, and published research on the postweaned period until 4 or 5 mo of age is lacking.

In September 1923, L. A. Maynard and L. C. Norris from Cornell University described feeding whole milk for 1 mo followed by a $24 \% \mathrm{CP}$ grain gruel for $1 \mathrm{mo}$ as a way to conserve milk and wean calves early (Maynard and Norris, 1923). In many of the early publications, authors wrote of feeding calves milk for the first month or so of life followed by feeding liquid skim milk until weaning as a way to conserve milk. Liquid skim milk was referenced as fairly abundant and free or low cost and was suggested as a good feed when combined with grains, if available. However, M. H. Berry at the University of Maryland reported that skim milk added to grains did not enhance growth in 2- to 5-mo-old calves (Berry, 1932). Those calves were fed 0.91 to $1.82 \mathrm{~kg}$ of dry feed with hay.

F. W. Atkeson, T. R. Warren, and G. C. Anderson from the Idaho Experiment Station in Moscow reported water intake in 30 heifers from birth to 24 mo of age (Atkeson et al., 1934). They reported the water requirements by age and in relation to DM intake. Water consumption was approximately 7 times DM ( $\mathrm{kg}$ of water/ $\mathrm{kg}$ of DM) consumed preweaning (before 6 mo of age) and approximately 4 times DM consumed until 26 mo of age.

In the first $20 \mathrm{yr}$ of the journal, calf papers did not report use of statistics to control or record variation and separate treatment means. Many experiments did not have 2 treatments or controls and were more observational than comparative. Typically fewer than 5 , and sometimes 1 or 2 , calves were used per treatment. Despite low numbers of calves in experiments, many researchers followed performance of calves beyond 6 mo of age. Experimental methods were often poorly described. Two experimental methods that are odd for us today but that were used in the early years of the journal were photographing calves to describe their look or condition and palpating the abomasum to check for curd formation and disappearance.

Other than those mentioned above, institutions with calf papers in the first $20 \mathrm{yr}$ of the journal included the USDA, Beltsville, Maryland; Pennsylvania State College; University of California, Davis; Michigan Agricultural Experiment Station, Lansing; Massachusetts Agricultural Experiment Station, Amherst; Alaska Agricultural Experiment Station, Kodiak; Panhandle
Agricultural Experiment Station, Goodwell, Oklahoma; and Ohio Agricultural Experiment Station, Wooster.

\section{7 to 1956}

The pace of scientific inquiry during the second $20 \mathrm{yr}$ of JDS (1937-1956) was affected by world events and redirection of public funding during the period of World War II. Nonetheless, numerous critical discoveries were made and published in the journal during this period. Many concepts fundamental to current knowledge and understanding of digestion, rumen development, and milk replacer formulation were developed during this period. In addition, the concept of using antibiotic growth promoters in dairy calf diets was first evaluated and developed during the 1950s.

\section{Antibiotic Feeding}

An area of tremendous research during these $20 \mathrm{yr}$ was use of antibiotics in liquid diets and solid feeds for calves. At least 24 papers studied effects of various antibiotics, particularly Aureomycin, on growth, health, feed efficiency, and rumen development. In some cases, improvements in growth rates approaching 30\% were reported (Loosli and Wallace, 1950; Rusoff et al., 1951). Research in feeding antibiotics to calves as growth promoters followed similar work in monogastrics in the 1950s. Much of the work was conducted by E. E. Bartley and colleagues at Kansas State University. These studies consistently showed improved growth and feed efficiency, reduced incidence of scours, and improved health when Aureomycin was included in calf diets. However, as pointed out by Murley et al. (1952), "Although the incidence of diarrhea was slightly lower among Aureomycin-fed calves, the comparatively infrequent occurrence of this disorder in all groups indicates that diminished scouring is not the sole cause of the improved growth resulting from feeding of the antibiotic. Moreover, whether the improved general appearance and condition of hair coat readily apparent among Aureomycin-fed calves was due to increased feed intake and reduced scouring or to other factors is not clear."

\section{Colostrum Feeding and Milk Digestibilities}

The importance of colostrum feeding to the health and growth of the calf was well established by 1937 . A series of important papers published in JDS by Parrish and colleagues at Kansas State between 1947 and 1953 reported the composition of colostrum. Some of these results are consistent with contemporary datafor example, first-milking colostrum nutrient content 
reported by Parrish et al. (1950). Another important finding from the group was that digestibility of fat and lactose by calves was consistently $>95 \%$ from 1 to $2 \mathrm{~d}$ of age through 14 to $17 \mathrm{~d}$ of age. On the other hand, protein digestibility averaged $92 \%$ during 1 to $2 \mathrm{~d}$ of age and then declined to 83 and $86 \%$ during 3 to 4 and 5 to $8 \mathrm{~d}$ of age, respectively, and then increased to $93 \%$ during 14 to $17 \mathrm{~d}$ of age.

\section{Milk and Milk Replacer}

Replacing whole milk in the diets of young dairy calves has long been an interest of calf researchers and a consistent theme in JDS. Very early work in the 1920s described replacement of milk at 4 wk of age with a gruel consisting of vegetable ingredients and blood meal as a high-quality protein source. Actual replacement of liquid milk with a liquid was not part of these early research trials. Development of modern products to effectively replace whole milk in the diets of young calves began with work conducted by Wiese et al. (1947) and Williams and Knodt (1949, 1950). Critical discoveries were made in areas including fat homogenization and sources, vitamin and mineral supplementation in replacement diets, and use of high-quality ingredients with high digestibility. Early diets incorporated CN, skim milk, and whey as primary protein sources. Inclusion of vegetable ingredients, including corn distillers solubles, beet pulp, oat flour, wheat red dog, banana meal, raw soybeans, and wood flock, likely impaired growth to some degree in early formulations. Nonmilk proteins included blood meal, blood flour, meat scraps, fish meal, and soy flour. These ingredients undoubtedly also affected digestion, particularly in very young calves. Initial attempts to replace whole milk were generally unsuccessful; however, continued development of technology improved nutrition so that calves fed these formulas performed acceptably. An important goal was to replace dried skim milk, which was the primary base for early successful replacement formulas. Many current papers published in JDS continue to attempt to replace milk proteins in milk replacer formulations.

\section{Fats and Oils}

Filled milks are skim milk compounded with any fat or oil other than milk fat to resemble milk or cream. Use of filled milks including different fats and oils to replace whole milk in the diets of young calves was a topic of some interest as attempts were made to replace whole milk. The dramatic effects of choice of fat source in milk replacers were perhaps best described by Gullickson et al. (1942). These researchers added fat sources $(3.5 \%)$ to skim milk $(96.5 \%)$ and fed calves for a few days to 6 mo of age. All fats were homogenized into skim milk before feeding. The researchers reported that calves fed corn, cottonseed, or soybean oils grew poorly and were unthrifty, listless, and emaciated. Many of these calves died or were taken off treatment due to poor health. Calves fed butterfat, lard, or tallow performed well, although the amount of carcass fat in calves fed lard or tallow was less than that in calves fed milk fat. Bate et al. (1946) and Barker et al. (1952) commented that homogenization of soybean oil improved growth, health, and hair coats of calves and ameliorated hair loss caused when unhomogenized fat and skim milk were fed. The inclusion of emulsifying agents with vegetable oils and skim milk was reported by Huff et al. (1951) and Kastelic et al. (1950), who also reported that fat globule size played an important role in fat digestion by calves.

\section{Rumen Development}

Perhaps the most significant contribution by researchers in the area of calf and heifer research during the period of 1937 to 1956 was the dramatic expansion in our understanding of ruminal development. Many of the fundamental principles regarding maturation of the ruminant gastrointestinal tract were reported during this time frame. Indeed, many of these papers are still referenced in papers published in the journal today.

Much of the work published during this period originated from The Ohio State University by workers including H. R. Conrad, J. W. Hibbs, W. D. Pounden, and T. S. Sutton. These researchers documented changes in populations of ruminal bacteria affected by age of calf and intake of dry feed (Pounden and Hibbs, 1948a,b). The concept of rumen inoculation with cud from mature animals was also tested extensively during the period (Pounden and Hibbs, 1948a; Conrad et al., 1950). Hibbs and colleagues also developed a high roughage system that relied on limited milk feeding and large amounts of high-quality forage and limited concentrates in the diet of young calves.

The critical role of VFA in physical and metabolic development of the rumen was reported by Warner et al. (1956) at Cornell University. This study clearly showed that extended milk intake slowed the rate of rumen development and that feeding forage did not stimulate maturation of the rumen wall to the same extent as calf starter. The authors hypothesized, "Because grain has been as effective as hay in stimulating the early growth of forestomach papillae and tissue, while milk was ineffective, it appears that dry feed per se is essential for the development of the fore-stomachs. Hay, because of its greater bulk, increased the capacity of the fore-stomachs without affecting the amount of tis- 
sue growth." They went on to suggest, "It seems logical that chemical products resulting from microbiological breakdown of dry feed might stimulate the development of tissue." Other work during this period documented temporal changes in ruminal concentrations of VFA and in vitro cellulose digestibility (Lengemann and Allen, 1955; McCarthy and Kesler, 1956) as well as changes in circulating concentrations of metabolic end products (McCarthy and Kesler, 1956).

\section{Vitamins and Minerals}

No area of calf and heifer research garnered more interest in JDS from 1937 to 1956 than vitamin and mineral nutrition in young calf diets. We counted 77 papers in the journal that referenced some aspect of vitamin or mineral nutrition in calf diets. Of particular interest was the role of vitamin A and carotene in calf health and growth.

Typically, diets almost devoid of vitamin A were fed to calves until signs of deficiency (loss of appetite, scouring with eventual loss of BW, and blindness) were observed. Then, various repletion diets were offered. Clinical outcomes included ophthalmoscopic evaluations and the animals' ability to avoid obstacles in dim light. Sources of carotene and vitamin A in several studies included carrots, alfalfa, and fish oils.

Colostrum was increasingly recognized as a source of important nutrients for the newborn calf in addition to providing passive immunity by absorption of Ig. Limited placental transmission of fat-soluble vitamins was also recognized, and dietary inclusion or injections were used to treat neonatal vitamin deficiencies. Several researchers reported that the vitamin A concentration in colostrum was 10 to 100 times greater than that in milk produced later in lactation (e.g., Stewart and McCallum, 1938) and that diet influenced the concentration of colostral vitamin A (Stewart and McCallum, 1942). Transmission of vitamin A to the calf via colostrum was also reported.

The role of adequate vitamin and mineral nutrition in the health of very young calves was increasingly clear in research conducted from 1937 to 1956. As Lundquist and Phillips (1943) stated, "It has been demonstrated that adequate vitamin $\mathrm{A}$ and nicotinic acid are the essential factors in the control of calf scours; the administration of these substances has controlled all types of scours thus far encountered, except that which accompanied septicemia in the newborn."

Mineral nutrition was also an important topic during this period of scientific inquiry. Papers evaluated the nutrition of magnesium, fluoride, manganese, molybdenum, and iron. The recognition of widespread cobalt deficiency in soils in certain regions of the United States and dietary amelioration of Co deficiency during the 1940s prompted research into the tolerance of calves to supplemental dietary Co (Keener et al., 1949).

As mentioned previously, proper statistical methods were not universally applied, though more papers included statistical methods later in the period. Typically, results from individual animals were reported, and studies often included fewer than 12 animals.

\section{7 to 1976}

During the 20-yr period of January 1957 through December 1976, a large number of universities in the United States and 1 in Canada contributed almost 150 papers on a variety of calf-related topics. Published studies investigated factors affecting calf birth weight, including genetics, cross-breeding programs, and breed. Foote et al. (1959) evaluated effects of genetics and maternal environment on gestation length and birth weight. Other studies from Illinois showed that birth weight and production were genetically independent (Legault and Touchberry, 1962). This work was a continuation of earlier breeding and genetics studies focused on calf birth weight and subsequent growth rates. Boyd and Hafs (1965) noted the increased use of beef bulls (Angus) in the dairy industry; 13\% of AI-bred dairy cattle were bred to beef bulls to reduce calf size. In addition, they showed that calves sired by Holstein bulls from Holstein cows were larger than those sired by Angus bulls. They also showed that certain Holstein bulls sired smaller calves than others and suggested that AI organizations evaluate and rank bulls based on birth size of their offspring. The effect of animal growth on experimental design was noted in several publications as it was related to the presentation of data in future research publications (Martin et al., 1962). Iowa State researchers concluded that calf nutrition experiments should be designed to prevent confounding breed, sex, and inbreeding effects with ration effects; a portion of these effects can be removed by using birth weight as the independent variable in an analysis of covariance (Martin et al., 1962).

During this 20-yr period, a variety of published papers looked at the physiology of the calf, both using the calf as an example animal species and seeking to understand the calf's uniqueness. Some of these studies included blood and blood constituents, pancreatic physiology, thyroid uptake of iodine, adrenalin metabolism, glucose metabolism, and nonesterified fatty acids. Several physiology papers used radioisotope methods and relatively low numbers of calves. Their findings were important and well done, utilizing techniques that today are not available or often possible. In many cases the low numbers of animals used was well justified due 
to the laborious and complex methods used. Their results were valid and remain valid today.

In 1969, Butler published a review of calf immunity that gave an up-to-date and complete summary of early-life immunity, IgG absorption, and related health research. This was a landmark paper covering the state of knowledge to that point and is still a very useful reference (Butler, 1969).

Research studying feeding antibiotics (primarily in milk replacers) to calves continued during this period. Researchers from Iowa State and Michigan State observed increased intake and growth in calves fed antibiotics (Bush et al., 1959). Results indicated that antibiotics had little effect on overall digestion and protein metabolism (Lassiter et al., 1958). The establishment of adult-type organisms and cellulose digestion were shown to be slow to develop and were hindered by Aureomycin and liberal milk feeding (Lengemann and Allen, 1959). Other studies showed that antibiotic feeding promoted animal growth and reduced diarrhea. Tennessee researchers published that the most effective method of feeding calves antibiotics was via milk and that after weaning the effects of antibiotic feeding were minimized (Swanson and Harris, 1958).

A large number of studies focused on rumen development during this time. Work from Warner's laboratory at Cornell hypothesized that rumen papillae growth resulted from metabolism of specific compounds by the rumen wall or their effect on blood flow in the rumen (Sander et al., 1959). Others studied rumen development using various VFA salts and manipulating rumen $\mathrm{pH}$. Tennessee workers studying hay feeding and diet type indicated that more than half of the calves in a particular study were ruminating effectively at $2 \mathrm{wk}$ of age (Swanson and Harris, 1958). The introduction of plastic sponges as a nonnutritive bulk source into the reticulorumen promoted increased rumen capacity and muscular development (Tamate et al., 1962). Feeding hay and starter in addition to milk resulted in forestomach development, which included papillary and muscular growth of the reticulorumen and pigment deposition in the rumen mucosa (Tamate et al., 1962). Conrad et al. (1958b) studied rumen development with the use of isotope marker techniques. Purdue researchers studied rumen development and noted that some feeding systems resulted in hyperkeratosis of the rumen, erosion of the rumen wall, and rumen plaques (Noller et al., 1962).

Oklahoma researchers (Gilliland et al., 1962) fed VFA salts to promote rumen development. Hodson et al. (1965) published classical work looking at butyrate absorption by the rumen wall mucosa. They used very complex physiological procedures such as rumencannulated calves with portal vein catheters and exte- riorized carotid or femoral arterial catheters to study ketone formation during passage of butyrate through the rumen wall using $\mathrm{C}^{14}$ butyrate. These Iowa State researchers noted the conversion of butyrate to BHB in the rumen mucosa, which resulted in little butyrate in the blood after butyrate infusion in the rumen. Kansas researchers conducted corroborating work related to rumen VFA absorption studies using $\mathrm{C}^{14}$. These data indicated that the very young calf can absorb and metabolize VFA whether the acids are produced in the forestomach or large intestine (Liang et al., 1967). Some researchers noted parallelisms between changes in ammonia- $\mathrm{N}$ in the rumen and blood urea and ammonia-N. Others looked at inoculation of a calf rumen with rumen contents of older animals, which resulted in establishing active populations of ciliate protozoa in early-weaned calves.

Milk replacer ingredients also were studied during this period to improve the quality and diversity of ingredients in replacers. Addition of lecithin improved digestibility of fat sources in milk replacers (Hopkins et al., 1959). Alternative protein sources, including soy and fish (Bouchard et al., 1973), as well as various fat sources and the level of fat feeding (Huber et al., 1968) were investigated. Other work looked at adding dried skim milk to calf starter. Swanson et al. (1969) concluded that the more efficient use of diets containing liquid milk was explained by the fact that liquid milk bypassing the rumen results in more readily metabolizable energy than does dry milk in the concentrate, which must go through the rumen. Various milk feeding systems were researched during this period. Ad libitum versus limited milk replacer feeding was studied in beef and dairy steers for veal production. Once-daily milk feeding compared with twice-daily feeding showed no increase in digestive disorders and did not reduce the growth and vigor of calves (Willett et al., 1969). Other milk feeding studies looked at the level of solids in milk replacer. We still see papers today that corroborate many of these findings.

Workers at several universities, including Kansas, Pennsylvania, and Minnesota, studied calf starter. Protein requirements in starters were discussed in light of the then-current NRC recommendations for protein and energy allowances for young calves (Morrill and Melton, 1973). They reported no differences between once- and twice-daily feeding of milk and 13 or $16.2 \%$ $\mathrm{CP}$ in starter with calves growing at 750 to $850 \mathrm{~g} / \mathrm{d}$ after 6 wk of age. They studied AA level in the blood as an outcome variable. One later study found that total free AA in the blood were affected by protein-to-energy ratios in the diet and that these also affected rumen development (Traub and Kesler, 1972). Results of many studies showed that the optimum protein-to-energy 
ratio in the young calf would be $46: 1$ or slightly less and helped establish protein requirements of the young calf (Brown and Lassiter, 1962; Bryant et al., 1967). Protein levels and hay versus grain feeding were studied by researchers in Kansas (Bartley, 1973). Protein levels of 12 and $16 \%$ starter were shown to be adequate with whole-milk feeding by researchers from Iowa State. In addition, several studies concluded that $16 \% \mathrm{CP}$ in starters under various feeding systems resulted in adequate growth over other levels studied.

Various feed ingredients were studied for calf starters during these years, including dry skim milk, rapeseed, cottonseed meal, sunflower, meat solubles, and soy products. Grain processing effects and fiber levels also were investigated. In addition to growth measurements, feed preference studies were often part of these starter comparisons. Also, some vitamin and mineral studies were done during this period to help refine requirements of the young calf.

During this 20-yr period a continuation of papers by J. W. Hibbs and H. R. Conrad related to the Ohio high-roughage system for calf feeding (Conrad et al., 1958a; Hibbs et al., 1961). These studies looked at a variety of forage and fiber feeding systems for calves. They focused on feeding silages, pasture, hay, alfalfa pellets, and high-fiber by-products for young calves through 3 to 4 mo of age. Their studies were done on both Holstein and Jersey calves and often included digestibility of fiber (cellulose) and N, with implications to rumen physiology and development and efficiency of feed utilization. Other researchers studied calves on pasture from 6 to $20 \mathrm{wk}$ of age (Kesler, 1962). Many of these studies found that feed intake, rates of gain, and feed efficiency were superior for calves fed higher fiber feeds and high-quality forages as long as rumen development was adequately addressed. Feed efficiency as TDN per kilogram of BW gain was the endpoint being studied in several studies comparing milk feeding levels or calf starters (Macleod et al., 1970).

Finally, a classic review of management, feeding, and housing studies was published (Appleman and Owen, 1975). This review summarized research related to calf feeding and management systems up to that point with an emphasis on maintaining calf growth and health while reducing labor and feed costs. Annual calf death losses were in the range of 6 to $15 \%$ during that period, as taken from various studies. Appleman and Owen (1975) discussed new work on nutrient levels in the diet and feeding systems, including feeding acidified milk with weaning at 12 to $28 \mathrm{~d}$. Another management paper that was referenced for many years was a survey of calf mortality and factors affecting it on a large number of farms in New York (Hartman et al., 1974). An interesting side note is that papers published during this period reported results in English units rather than metric units.

\section{7 to 1996}

In the 20-yr period from 1977 to 1996, more than 400 articles on calf nutrition and management were published in JDS. With the growing research interest in calves, the North Central Regional Research Committee on Improving Large Dairy Herd Management published a paper outlining the standardized procedures for conducting and reporting data from calf experiments (Larson et al., 1977). Many of the guidelines are still in use today, aiding the interpretation of nutrition and management data across research studies.

\section{Colostrum}

An active area of calf nutrition research from the late 1970s to mid 1980s was colostrum quality, feeding, and preservation; more than 60 such research articles were published in the journal during this time. A series of articles in 1979 by Stott and colleagues at the University of Arizona on timing of first colostrum feeding, rate and amount of Ig absorption, and method of feeding colostrum described the basic principles and practices essential for successful passive immunity in calves (Stott et al., 1979a,b,c,d). Bush and Staley (1980) presented a detailed description of Ig absorption from the intestinal tract, cessation of absorption, and factors affecting absorption in a symposium paper. The amount of Ig in the serum of the calf at $24 \mathrm{~h}$ of age is in positive linear relationship with the amount and concentration of colostral Ig fed. Immunoglobulin concentration in the first feeding of colostrum is more important than the volume of colostrum fed. Fleenor and Stott (1980) developed a simple and rapid method based on specific gravity for determining Ig concentration in colostrum.

From late 1970 to early 1980, more than 20 research articles on preservation and feeding of excess colostrum or unsalable milk appeared in the journal. The review on preservation and feeding of surplus colostrum by Foley and Otterby (1978) and the 25-yr summary of calf nutrition and management (Otterby and Linn, 1981) summarized fresh and preserved colostrum feeding. Fermented colostrum, acid-preserved fermented colostrum, and unsaleable milk all supported good growth and health in calves when fed during the preweaning period. The review on feeding fresh and fermented mastitic milk to calves by Kesler (1981) found no differences in calf growth, performance, or health disorders with feeding mastitic liquid feeds compared with nonmastitic liquid feeds. 
A National Dairy Heifer Evaluation Project surveyed 1,811 farms in 1991 and 1992 (Heinrichs et al., 1995). The percentage of farms feeding various liquid feeds to calves after the first $24 \mathrm{~h}$ of age was $80 \%$ for fresh or soured colostrum, $70 \%$ for whole milk, $65 \%$ for milk replacer, and about 55\% each for mastitic and antibiotic milk. Larger farms fed more mastitic and antibiotic milk than smaller farms that fed more milk replacer.

\section{Milk Replacer Protein}

Replacing a portion of milk protein in milk replacers with vegetable and fish protein was shown in several studies during the 1980s to result in poor calf performance and increase the incidence of diarrhea in calves, particularly in calves less than 3 wk of age (Campos et al., 1982). The lack of clot formation in the abomasum - and thus a fast passage rate of proteins and other nutrients from the abomasum into the intestine when soy, fish, and other alternative proteins were fed-was thought to be the cause of diarrhea and reduced performance. The prevailing premise at this time was that the lack of clot formation indicated a low-quality milk replacer (Gaudreau and Brisson, 1980). Although the nonclotting premise may have been true for some protein sources, it was not for whey proteins, which were becoming the major protein source in milk replacers in the 1980s (Petit et al., 1989).

Seegraber and Morrill (1982) found that antigenicity and other factors in soy flour and soy concentrate caused morphological changes to the intestinal villi, impairing absorption of protein and other nutrients and leading to increased diarrhea. The changes in intestinal villi of calves fed soy protein were similar to those associated with viral infections in calves, celiac disease in man, and transmissible gastroenteritis in pigs. Silva et al. (1986) also found low weight gain, diarrhea, and villus atrophy in calves when soy protein concentrate accounted for $66 \%$ of the total protein in milk replacer. Despite considerable research in the 1980s, no alternative protein source emerged as an equivalent to milk protein in supporting good growth and health in calves, especially calves less than 3 wk of age.

In the 1990s, plasma protein started to be evaluated as a partial substitute for milk protein in milk replacer. Advantages of plasma protein over other protein sources were that it provided (1) highly digestible protein, (2) a desirable balance of AA, and (3) Ig localized in the intestine to protect against certain bacteria and viruses. Morrill et al. (1995) reported that either bovine or porcine plasma was an acceptable replacement for $25 \%$ of the milk protein in milk replacer for calves weaned at $42 \mathrm{~d}$ of age. Calves fed plasma containing milk replacer gained equal to all calves fed milk protein replacer the first 3 wk of feeding but significantly better than all calves fed milk protein wk 4 through 6. Quigley and Bernard (1996) also replaced 25\% of the protein in milk replacer with bovine plasma and achieved growth and performance equal to that of calves fed an all milk protein milk replacer through $56 \mathrm{~d}$ of age.

\section{$A A$}

Supplementation of milk replacer or milk diets with AA received very little attention during the period 1977 to 1996. Foldager et al. (1977) reported that Met intakes of calves fed milk replacer should be 2.75 to $2.95 \mathrm{~g} / 100 \mathrm{~g}$ of CP ingested. Tzeng and Davis (1980) reported that requirements for DL-Met ranged from 0.17 to $0.23 \mathrm{~g} / \mathrm{d}$ per kilogram of BW and requirements for Lys ranged from 0.27 to $0.31 \mathrm{~g} / \mathrm{d}$ per kilogram of $\mathrm{BW}$ in neonatal calves.

\section{Fat}

Very little research on fat sources in milk replacers was conducted during the 1980s and early 1990s. Jenkins et al. (1986) evaluated several lipid sources and forms of fat for addition to milk replacer and concluded that tallow and canola oil resulted in the best DMI and performance of calves. Oils high in linoleic acid (e.g., corn) caused diarrhea, whereas oils high in oleic acid (e.g., canola) did not. Fats and oils with high amounts of free fatty acids reduced milk replacer intake, fatty acid digestion in the calf, and overall calf performance.

Calves housed in outdoor hutches supplemented with extra fat in cold weather increased BW gains during the first month of life (Jaster et al., 1992). Scibilia et al. (1987) estimated that the maintenance energy requirement increased $32 \%$ as the environmental temperature decreased from $10^{\circ} \mathrm{C}$ to $-4^{\circ} \mathrm{C}$.

\section{Minerals}

Two locations conducted most of the calf mineral research in the 1980s and early 1990s. Research at the Animal Research Center, Agriculture Canada in Ottawa led by Jenkins, Hidiroglou, and Kramer focused on trace minerals in the preweaned calf, whereas research at the University of Georgia led by Miller and Neathery examined both macro- and trace-mineral toxicity in postweaned calves. A synopsis of the research follows.

\section{Trace Minerals in Milk Replacer}

Copper toxicity in calves occurred at $1,000 \mathrm{mg} / \mathrm{kg}$ in milk replacer (Jenkins and Hidiroglou, 1989). The safe 
upper level of $\mathrm{Cu}$ in milk replacer for feeding to calves was $50 \mathrm{mg} / \mathrm{kg}$ (Jenkins and Hidiroglou, 1989). Jenkins and Hidiroglou (1990) suggested a 10-mg/kg I level in milk replacer because feeding $50 \mathrm{mg} / \mathrm{kg}$ of I or more significantly increased I content of nonthyroid tissues. Iron concentrations of $5,000 \mathrm{mg} / \mathrm{kg}$ in milk replacer reduced feed intake and weight gain of preruminant calves (Jenkins and Hidiroglou, 1987). Consumption of milk replacer containing $1,000 \mathrm{mg} / \mathrm{kg}$ of $\mathrm{Mn}$ reduced feed intake and weight gain of calves, whereas 5,000 $\mathrm{mg} / \mathrm{kg}$ of $\mathrm{Mn}$ in milk replacer was toxic and resulted in calf deaths (Jenkins and Hidiroglou, 1991). Calves readily absorbed and metabolized Se from sodium selenate or selenite and tolerated up to $5 \mathrm{mg} / \mathrm{kg}$ of Se in milk replacer (Jenkins and Hidiroglou, 1986). Above $500 \mathrm{mg} / \mathrm{kg}$ of Zn in milk replacer, calves reduced feed intake and weight gain (Jenkins and Hidiroglou, 1991). Forty milligrams per kilogram of $\mathrm{Zn}$ in milk replacer was adequate; increased concentrations provided no additional benefit in calf performance.

\section{Macrominerals in Diets of Weaned Calves}

Adding 5\% fat to a calf starter did not affect Ca absorption (Fielding et al., 1985). The primary factor affecting $\mathrm{Ca}$ absorption is $\mathrm{Ca}$ content of the feed, with increasing amounts decreasing apparent absorption. Up to $1.31 \%$ Ca can be included in starter with no reduction in feed intake or performance (Alfaro et al., 1988). Calves adapted quickly to a diet deficient in $\mathrm{Cl}(0.038 \%)$ by reducing $\mathrm{Cl}$ in plasma, saliva, and urine (Burkhalter et al., 1980). Magnesium toxicity was exhibited (reduced feed intake, diarrhea) in calves fed diets containing more than $1 \% \mathrm{Mg}$, but no effects on performance were found with 0.25 or $0.7 \% \mathrm{Mg}$ diets (Quillian et al., 1980). Miller et al. (1987a) suggested that $\mathrm{P}$ content of diets fed to 2 - to 4-mo-old calves not be less than $0.32 \%$ of the diet DM. In palatability studies on $\mathrm{K}$ supplements, 90-d-old calves found $\mathrm{KHCO}_{3}$ and $\mathrm{KCH}_{3} \mathrm{CO}_{2}$ more palatable than $\mathrm{KCl}$ and found $\mathrm{K}_{2} \mathrm{CO}_{3}$ the least palatable (Neathery et al., 1980).

\section{Trace Minerals in Diets of Weaned Calves}

Aluminum at $0.2 \%$ in calf starter significantly reduced feed intake $(17 \%)$ and weight gain $(47 \%)$ of weaned calves (Crowe et al., 1990). Miller et al. (1991) reported that calves fed starters containing more than $500 \mathrm{mg} / \mathrm{kg}$ of supplemental Fe from ferrous carbonate tended to have lower intakes than calves fed starter with no supplemental Fe, but no adverse health effects were observed in calves fed the higher concentrations of Fe. Manganese absorption from a purified diet or cornskim milk diet was the same in calves, but absorption of Mn from the same diets fed to rats was much greater from the corn-skim milk diet than from the purified diet (King et al., 1980). Fermentation of feeds in the rumen was thought to have produced products that aided Mn absorption postruminally. Intestinal absorption of Mn from diets is very low, and Miller et al. (1987b) showed that absorption is what limits $\mathrm{Mn}$ in body tissues and not metabolism. Lead toxicity occurred in 74-d-old calves fed diets containing 500, 1,500, or 4,500 $\mathrm{mg} / \mathrm{kg}$ of $\mathrm{Pb}$ (Logner et al., 1984). Death loss was 25 and $100 \%$ within $10 \mathrm{~d}$ after feeding diets containing 1,500 and $4,500 \mathrm{mg} / \mathrm{kg}$ of $\mathrm{Pb}$, respectively.

\section{Vitamins}

The importance of vitamin $\mathrm{E}$ in calf health and performance received the most attention from 1980 to 1996. Kansas State researchers provided recommendations of 125 to $250 \mathrm{IU}$ of vitamin E/calf per day for good health and performance from birth to $6 \mathrm{mo}$ of age (Reddy et al., 1987). Vitamins A, C, D, and K also were evaluated during this period, but to a lesser extent than vitamin $\mathrm{E}$.

\section{Calf Starter}

Throughout the 1970s, 1980s, and 1990s, the primary objective of most calf research was to examine how to wean healthy, adequately grown calves at an early age (generally $<30$ d of age). Kertz et al. (1979) summarized 30 experiments published in JDS during the 1970s and $3 \mathrm{yr}$ of calf research data from a commercial facility to show that calves could achieve adequate growth and development for weaning at $28 \mathrm{~d}$ of age. In studies where calf growth was considered adequate or better $(>0.32$ $\mathrm{kg} / \mathrm{d}$ ) for early weaning, the quality and amount of calf starter consumed was the major factor contributing to the success of early weaning. Jenny and O'Dell (1981) fed calves milk replacer at 8 or $10 \%$ of BW with DM concentrations of 10,15 , and $20 \%$ from birth to $6 \mathrm{wk}$ of age to show the effect of the liquid feeding program on starter consumption. Starter was withheld from calves the first $3 \mathrm{wk}$ but offered ad libitum to all calves from 4 to 12 wk. Average daily gain of calves fed milk replacer at 8 or $10 \%$ of BW was the same $(0.67$ and 0.68 $\mathrm{kg} / \mathrm{d}$ ) from 4 to 12 wk of age. The DM concentration of milk replacer had no effect on gain during wk 4 to 6; however, during wk 7 to 8 , immediately postweaning, ADG were $0.56,0.60$, and $0.38 \mathrm{~kg}$ for calves fed milk replacer at 10,15 , or $20 \% \mathrm{DM}$, respectively. Intake of starter during wk 4 to 6 decreased as milk replacer DM increased. By 12 wk of age with unrestricted access to starter, ADG of calves fed 10, 15, or $20 \%$ of DM milk replacer were similar. 
Research on calf starter ingredients, nutrient composition, and additives was minimal in the 1980s and 1990s given the importance of starter intake to the success of early weaning. Klein et al. (1987) showed that calves could be weaned at $17 \mathrm{~d}$ of age when fed a milk ingredient pelleted prestarter $(22 \% \mathrm{CP}, 12 \%$ fat, and $0 \%$ fiber) until 4 wk of age. A starter containing 10 or $20 \%$ alfalfa also was fed the first $4 \mathrm{wk}$ and then as the only starter from wk 5 to 10 . Calf weight gain at $10 \mathrm{wk}$ of age was slightly less for calves weaned at $17 \mathrm{~d}$ compared with $28 \mathrm{~d}$, but at 6 mo of age BW gain of calves was not different. Feeding a highly digestible prestarter supported early rumen development and demonstrated that VFA content in the rumen is more likely responsible for rumen development than physical fiber.

\section{Calf Starter Protein and Energy}

Luchini et al. (1991) reported no advantage in calf performance to feeding a $25 \%$ versus $20 \% \mathrm{CP}$ starter to calves weaned at 26 or $42 \mathrm{~d}$ of age. Akayezu et al. (1994) fed calf starters with 15.0, 16.8, 19.6, or $22.4 \%$ $\mathrm{CP}$ to calves from 4 to $56 \mathrm{~d}$ of age. Daily gain of calves increased linearly with increasing $\mathrm{CP}$ in the starter; however, after weaning, calves fed the $19.6 \%$ CP starter had the best growth performance.

Soybeans add both protein and energy to a calf starter; however, processing is required to remove some of the antinutritional factors. Raw soybeans and soybeans roasted at 138,171 , or $191^{\circ} \mathrm{C}$ were included in calf starters for feeding from birth through $8 \mathrm{wk}$ of age (Abdelgadir et al., 1984). Calves fed soybeans roasted at $191^{\circ} \mathrm{C}$ consumed the most starter and gained the most during the $8 \mathrm{wk}$, but only slightly better than calves fed starter with soybeans roasted at $171^{\circ} \mathrm{C}$. Calves fed starter containing raw soybeans had the lowest feed intake, lowest weight gain, and highest fecal score. Reddy et al. (1993) found that roasting soybeans at $146^{\circ} \mathrm{C}$ followed by 30 min of steeping resulted in the best calf performance. Luchini et al. (1993) reported that adding 5\% fat to a starter had no effect on intake or calf performance through $42 \mathrm{~d}$ of age. Although fat in milk replacer and starter can be a good source of energy for calves, feeding a high-fat milk replacer with a high-fat calf starter depressed feed intake and reduce calf performance (Kuehn et al., 1994). High-fat milk replacer $(21.6 \%$ DM) depressed DMI before and after weaning, and high-fat calf starter $(7.3 \% \mathrm{DM})$ depressed DMI after weaning. Before weaning, calves gained the most BW when fed the low-fat $(15.6 \% \mathrm{DM})$ milk replacer; after weaning, calves fed the low-fat $(3.7 \% \mathrm{DM})$ calf starter gained the most BW.

\section{Water}

Providing free access to water early in life encourages calf dry feed intake. In a study where free-choice water was withheld the first 4 wk of life, calves fed milk replacer had a $38 \%$ lower BW gain and $31 \%$ reduction in calf starter intake compared with calves fed milk replacer with ad libitum water (Kertz et al., 1984). Very few studies consider and report free water intake as a factor in response to dietary treatments.

\section{7 to 2016}

Research on issues with calves continued to increase during this 20-yr period, as evidenced by publication of more than 580 articles in JDS as well as many more in other refereed journals. In addition to papers contributed by several universities in the United States and Canada, the number of papers authored by scientists at universities and institutes in other countries increased dramatically during the period January 1997 through December 2016.

Increased interest in calves likely resulted in part from changes in the industry, with larger farms (USDA, 2002) and more custom calf-raising enterprises (Walker et al., 2012). Publication of the seventh revised version of Nutrient Requirements of Dairy Cattle (NRC, 2001), which contained an entire chapter on calf nutrition along with a mathematical model for calculating calf requirements, helped to emphasize variable nutrient needs for growth and cold stress. Kertz and ChesterJones (2004) published an updated review on guidelines for measuring and reporting necessary background information by researchers, which improved the quality of many research studies; however, this remains an area for improvement.

\section{Colostrum}

During the period 1997 to 2016, research continued to define factors that affect attainment of adequate passive immunity, emphasizing the mass of colostral IgG consumed early after birth as affected by timing of feeding, amount fed, and colostrum quality (Morin et al., 1997). A major research theme involved transmission of disease organisms from dam to calf via colostrum or waste milk, related to biosecurity protocols as well as calf health. Stewart et al. (2005) demonstrated the extent of potential bacterial contamination of colostrum on farms due to poor hygiene during milking, failure to quickly cool or preserve colostrum for storage, or improper cleaning and sanitation of feeding devices. 
Although on-farm pasteurization of waste milk was becoming more widely used, pasteurization of colostrum is more problematic because of its high protein content, which can increase viscosity and coagulation if overheated (Godden et al., 2003). Godden and colleagues at the University of Minnesota defined conditions $\left(60\right.$ min at $60^{\circ} \mathrm{C}$ ) for successful batch pasteurization of colostrum (McMartin et al., 2006) that decreased colostral bacteria counts with minimal damage to Ig, vitamins $\mathrm{A}$ and $\mathrm{E}$, and $\beta$-carotene (Johnson et al., 2007; Donahue et al., 2012). Heat-treated colostrum resulted in increased $\operatorname{IgG}$ in calf serum at $24 \mathrm{~h}$ after birth and greater apparent absorption efficiency of IgG (Johnson et al., 2007); these findings were confirmed by Penn State University researchers (Elizondo-Salazar and Heinrichs, 2009). Moreover, feeding heat-treated colostrum decreased morbidity (particularly diarrhea) in young calves (Godden et al., 2012; Gelsinger et al., 2015). Malmuthuge et al. (2015) reported that calves fed heat-treated colostrum had greater colonization of bifidobacteria and less Escherichia coli than those fed unheated colostrum, suggesting a possible reason for improved gut health.

Another area of active research was development and evaluation of colostrum supplements and colostrum replacers, with Ig derived from either bovine blood fractions (plasma or serum) or dried colostrum. Although earlier experiments with colostrum supplements from dried colostrum showed that IgG absorption was not consistently improved and that apparent absorption efficiency decreased (Hopkins and Quigley, 1997; Morin et al., 1997; Arthington et al., 2000a), subsequent colostrum replacer products derived from dried colostrum resulted in acceptable passive transfer when fed at higher doses (Godden et al., 2009). Products derived from serum or plasma proteins were effective as supplements (Arthington et al., 2000b). Colostrum replacer products derived from spray-dried and concentrated bovine serum were shown to be effective as sources of passive immunity (Quigley et al., 2001; Swan et al., 2007; Priestley et al., 2013).

In addition to the importance of colostrum for activation of the immune system, colostrum contains many hormones and growth factors of the endocrine system, which interact with cells in the gut to program and activate the digestive system and muscle (Ontsouka et al., 2016). Research groups led by J. W. Blum and R. M. Bruckmaier (University of Berne, Switzerland) and H. M. Hammon (Institute of Nutritional Physiology "Oskar Kellner," Leibniz Institute for Farm Animal Biology, Germany) were major contributors to this effort.

\section{Nutrition}

The majority of articles published during this period dealt in some way with nutrition. The most prolific research group during this time was that of T. M. Hill and colleagues at Akey (subsequently Provimi and Cargill), who researched a wide variety of topics related to milk replacer composition and feeding rates, starter composition, provision of forage, and other management topics.

\section{Increased Rates of Milk or Milk Replacer Feeding}

With the objective of better defining energy requirements for growth of Holstein calves, Diaz et al. (2001) fed calves a milk replacer containing 30\% CP (to ensure that protein would not limit growth) and $20 \%$ fat in amounts calculated to provide ADG of 500, 900, or $1,400 \mathrm{~g} / \mathrm{d}$. Body composition was measured when calves reached 65,85 , and $105 \mathrm{~kg}$ of BW. Calves were fed no starter. Actual daily gains from birth to harvest were 560,973 , and $1,100 \mathrm{~g} / \mathrm{d}$; protein deposition $(140,204$, and $247 \mathrm{~g} / \mathrm{d})$ increased linearly, whereas fat deposition (44, 154, and $161 \mathrm{~g} / \mathrm{d}$ ) increased less from the middle to highest feeding rate. Jasper and Weary (2002) compared calves fed milk at $10 \%$ of BW with those allowed ad libitum access to milk from a teat along with free-choice access to starter and hay. Ad libitum consumption of milk increased to more than 9 $\mathrm{kg} / \mathrm{d}$ by d 4 and ranged between 9 and $10 \mathrm{~kg} / \mathrm{d}$ through d 35. However, consumption of starter and hay was less than that in the restricted-fed calves. Ad libitumfed calves gained BW at more than twice the rate of controls before weaning ( 0.78 vs. $0.36 \mathrm{~kg} / \mathrm{d})$ and were $10.5 \mathrm{~kg}$ heavier at d 35; however, as observed in earlier studies, growth rates were lower during the period of weaning and postweaning.

These reports stimulated several research groups to compare so-called intensified or accelerated milk feeding programs with conventional limit-fed programs. Findings were generally consistent among studies that preweaning growth rates were increased by greater milk feeding rates, but because starter intake was suppressed, the immediate postweaning growth rates were lower than with conventional programs. Research by T. M. Hill and colleagues at the Akey research facility (now Cargill) and A. Bach at IRTA in Barcelona, Spain, evaluated ad libitum or high milk feeding rates versus intermediate or moderate programs. Feeding moderate amounts of milk replacer $(\sim 6 \mathrm{~L} / \mathrm{d}$ or $0.68-0.75 \mathrm{~kg} / \mathrm{d}$ of solids) resulted in greater growth rates than controls but larger starter intake than calves fed $8 \mathrm{~L} / \mathrm{d}$ or $\geq 1$ 
$\mathrm{kg}$ /d of milk solids (Hill et al., 2010; Bach et al., 2013). Liang et al. (2016) demonstrated that Jersey calves in the first week of life were well able to digest and utilize protein from large amounts of milk.

\section{Protein Energy Effects on Growth and Body Composition}

Following the Cornell study (Diaz et al., 2001), other researchers studied how amounts of protein relative to fat or carbohydrate affected body composition and composition of gain. Research by Tikofsky et al. (2001) demonstrated that greater fat intake from milk replacer was partitioned mainly to body fat deposition. Bascom et al. (2007) reported similar findings in Jersey calves. Bartlett et al. (2006) used 2 feeding levels (1.25 or $1.75 \%$ of $\mathrm{BW}$ as $\mathrm{DM}$ ) and $4 \mathrm{CP}$ concentrations (14, 18,22 , or $26 \%$ ) in milk replacer with calves slaughtered after 5 wk. Greater feeding rate increased growth rate, and increasing $\mathrm{CP}$ percentage increased growth rate and lean tissue deposition. Labussiere et al. (2008) reported similar results with veal calves. More recently, Silva et al. (2015) determined the effects of amounts of milk and starter on body composition of Holstein $x$ Gyr calves.

\section{Protein Sources in Milk Replacers}

A major change in the milk replacer industry during this period was the near-total replacement of skim milk or CN in "all milk protein" milk replacers with whey proteins from dried whey, whey protein concentrate, delactosed whey, or whey protein isolates (Davis and Drackley, 1998). Penn State University researchers (Terosky et al., 1997; Lammers et al., 1998) found that whey proteins were utilized by the calf at least as well as skim milk proteins.

Researchers continued to examine nonmilk proteins for their ability to replace skim milk or whey proteins in milk replacers. Researchers at L'Institut National de la Recherche Agronomique in France (Montagne et al., 2000) found that intestinal endogenous secretions, including mucin, were greater when calves were fed milk replacers containing soy protein concentrate or partially hydrolyzed soy protein isolate compared with when calves were fed milk replacers containing skim milk proteins. Guilloteau et al. (2011) determined that more pancreatic juice protein or trypsin were needed to achieve maximal nutrient digestibility when calves were fed milk replacer containing soy protein concentrate compared with a skim milk protein control. Drackley et al. (2006) found that supplemental L-glutamine (1\% of diet) did not improve growth or health in calves fed a milk replacer with $60 \%$ of the milk protein replaced by soy protein concentrate.

\section{$A A$}

Kanjanapruthipong (1998) found that supplementing a milk replacer containing $43 \%$ of the protein as soy with Lys, Met, and Thr significantly improved ADG and $\mathrm{N}$ retention compared with the unsupplemented diet. In a series of experiments, Hill et al. (2008) determined that the Lys requirement for 48-kg calves gaining $0.46 \mathrm{~kg} / \mathrm{d}$ was $17 \mathrm{~g} / \mathrm{d}$, with Met:Lys of 0.31 and Thr: Lys of 0.60 . Other studies confirmed the importance of supplementing at least Lys and Met when using protein sources other than milk proteins.

\section{Fat and Fatty Acid Profiles}

Little research was conducted on different fat sources during this period. However, several groups reported that providing more essential fatty acids, particularly the n-3 fatty acids, improved health and growth. Mills et al. (2010) found that calves fed greater amounts of medium-chain fatty acids from coconut oil deposited more dietary energy and fat than controls during cold stress. A combination of medium-chain and essential fatty acids plus sodium butyrate resulted in improved growth and measures of health (Hill et al., 2011; Esselburn et al., 2013).

An interesting study in veal calves showed that a high dietary concentration of calcium (1.24\%) decreased apparent digestibility of fat by 5.6 percentage units and increased fecal bile acid excretion by $90 \%$ (Xu et al., 1998). The authors' hypothesis was that high Ca would form insoluble complexes with $\mathrm{Mg}$ and $\mathrm{P}$ and as a result would bind bile acids and inhibit their reabsorption. As a result, a limitation of bile acids available to form micelles for fat absorption would decrease fat digestibility.

\section{Minerals}

Kegley et al. (1997) fed calves milk replacers with no supplemental $\mathrm{Cr}$ or $0.4 \mathrm{mg} / \mathrm{kg}$ of $\mathrm{Cr}$ from CrCL3 or Cr-nicotinic acid complex. Supplementation of Cr had minimal effect on growth or intake but did increase glucose responses to insulin challenge. Depew et al. (1998) compared control calves with those fed milk replacer and starter supplemented with $1 \mathrm{mg} / \mathrm{kg}$ of $\mathrm{Cr}$ from $\mathrm{Cr}$ tripicolinate. Only minor effects on growth and metabolism were noted, and only during the first few weeks of life.

Kincaid et al. (1997) supplemented a basal starter diet $(60 \mathrm{mg} / \mathrm{kg}$ of $\mathrm{Zn})$ with 150 or $300 \mathrm{mg} / \mathrm{kg}$ of $\mathrm{Zn}$ in 
the form of Zn-Met and Zn-Lys or $300 \mathrm{mg} / \mathrm{kg}$ of $\mathrm{ZnO}$ to calves from 6 to 12 wk of age. Feed intakes and BW gains were not affected. Absorption and retention of $\mathrm{Zn}$ were greater for the Zn-Met and Zn-Lys groups than for the $\mathrm{ZnO}$ group, but the extra $\mathrm{Zn}$ did not affect immune function. Wright and Spears (2004) supplemented a basal starter diet with $20 \mathrm{mg} / \mathrm{kg}$ of $\mathrm{Zn}$ from $\mathrm{ZnSO}_{4}$ or $\mathrm{Zn}$ proteinate. Gain and intake were not affected by diets. When calves were fed $500 \mathrm{mg} / \mathrm{kg}$ of $\mathrm{Zn}$ from the same sources, tissue $\mathrm{Zn}$ was increased more by $\mathrm{Zn}$ proteinate than by $\mathrm{ZnSO}_{4}$. Zinc status in veal calves was impaired in calves fed a combination of skim milk plus soybean protein despite higher dietary Zn, likely due to the presence of phytate in the soy protein source (Xu et al., 1997).

Gengelbach and Spears (1998) fed calves a Cudeficient milk replacer for $8 \mathrm{wk}$, and then after weaning calves were fed a control (nonsupplemented) diet, $10 \mathrm{mg} / \mathrm{kg}$ of $\mathrm{Cu}$ from $\mathrm{CuSO}_{4}, 5 \mathrm{mg} / \mathrm{kg}$ of Mo from $\mathrm{Na}_{2} \mathrm{MoO}_{4}$, or $5 \mathrm{mg} / \mathrm{kg}$ of $\mathrm{Cu}$ from $\mathrm{CuSO}_{4}$ and $5 \mathrm{mg} /$ $\mathrm{kg}$ of Mo. Calves fed either the $\mathrm{Cu}$ - or Mo-only diets gained BW more efficiently than those fed the control or $\mathrm{Cu}+\mathrm{Mo}$ diets, but calves fed the Mo diet had more serious signs of $\mathrm{Cu}$ deficiency.

\section{Vitamins}

Although little research was conducted on watersoluble vitamins during this period, several research groups reported on fat-soluble vitamins. Franklin et al. (1998) showed that ratios of vitamins A and E should be considered and that high doses of vitamin A to calves while scouring could be detrimental. Nonnecke et al. (1999) reported a negative correlation between plasma retinol and vitamin E concentrations, suggesting that vitamin A influences the absorption and distribution of vitamin E. Hammell et al. (2000) suggested that 1,700 IU of vitamin $\mathrm{A} / \mathrm{d}$ was adequate for calves, whereas Swanson et al. (2000) reported evidence that milk replacer should contain 11,000 IU of vitamin A/kg.

\section{Feeding Waste Milk}

Butler et al. (2000) and Stabel (2001) showed that pasteurization of waste milk was effective in destroying Mycoplasma sp. and Mycobacterium paratuberculosis, respectively. Ultraviolet light treatment is being used by some producers to reduce (but not eliminate) bacterial counts in nonsaleable milk fed to calves. In a field study conducted by Gelsinger et al. (2014) on 9 Pennsylvania farms, UV treatment of raw milk intended for feeding to calves resulted in large reductions of bacterial counts. Langford et al. (2003) found that increasing amounts of penicillin residues in waste milk increased antibiotic resistance of gut bacteria in calves, supporting earlier recommendations not to feed milk from antibiotic-treated cows.

\section{Starter Composition and Management}

Research continued during the 20-yr period beginning in 1997 to maximize starter intake and optimize calf performance from starters. Lesmeister and Heinrichs (2004) examined different degrees of corn grain processing, including whole, dry rolled, roaster rolled, and steam flaked. Calves fed starter containing roasterrolled corn grain had greater structural growth and ruminal butyrate concentration than calves in other treatment groups. The physical form of oats (whole vs. ground) did not affect digestive development in calves (Suarez-Mena et al., 2015). When iso-starch (25\% of DM) diets were fed to calves, consumption of starter $\mathrm{DM}$ and $\mathrm{BW}$ gain were greater when starter contained corn than when starter contained barley, oats, or wheat (Khan et al., 2007).

A series of experiments conducted at the University of Guelph and Institució Catalana de Recerca i Estudis Avançats (ICREA) in Spain demonstrated that calves have preferences (presumably based on palatability) for energy- and protein-providing ingredients. For example, Miller-Cushon et al. (2014) found that wheat meal was the highest ranked energy ingredient, whereas rice meal and corn gluten feed were lowest ranked; among protein ingredients, soybean meal was highest ranked and corn gluten meal was lowest ranked. Of interest was that these preferences were still identifiable when ingredients were combined into mixtures.

Some other novel findings were presented during this time. Kim et al. (2012) showed that fermented soybean meal was better utilized than regular soybean meal in just-weaned calves. Beiranvand et al. (2016) found that adding water to dry starter to either $75 \%$ or $50 \%$ final DM improved starter intake and increased ADG during hot summer weather.

Due to changes in the European Union regulations for veal production, the influence of solid feed consumption by veal calves was a prominent research topic. Researchers explored the effects of amount of solid feed as well as the composition of that feed on nutrient utilization and welfare in veal calves (Suárez et al., 2006; Berends et al., 2012; Webb et al., 2015).

\section{Rations and Feeding Behavior}

A new area of investigation during this period evaluated factors related to preference, palatability, and sorting of feed mixtures in young calves (Miller-Cushon et al., 2013a,b; Groen et al., 2015). 


\section{Provision of Forage}

Research during the 2000s and 2010s again explored the effect of provision of small amounts of forage to preweaned and postweaned calves. Coverdale et al. (2004) found that 5 to $10 \%$ chopped forage in starter improved ADG. Khan et al. (2011) reported that provision of hay improved performance in calves consuming higher quantities of milk. Castells et al. (2012) compared intakes and performance of calves offered different forages and showed that alfalfa hay was consumed in the greatest amounts with no benefit to ADG, whereas calves consumed approximately $5 \%$ of their total ration as chopped straw but had greater ADG. Suarez-Mena et al. (2016) evaluated different particle sizes of straw included at 5\% of starter DM: 0.82 (in pellet), 3.04, 7.10, and $12.7 \mathrm{~mm}$. Size of straw particles did not markedly affect rumen development or organ size. Although research in this area is subject to several potential confounding factors (Kertz, 2007), at present it appears that small amounts $(\sim 5 \%)$ of chopped straw or other lower nutrient forages may improve overall intake and utilization of starter feed when pelleted for improved growth.

\section{Weaning}

When and how to wean calves became a topic of interest again with the advent of the intensified milk programs in which larger amounts of milk or milk replacer delay increases of starter intake. Weaning at 8 wk instead of 6 wk (Eckert et al., 2015) and stepping down milk intake by use of automated feeders (Sweeney et al., 2010) appear to be the best methods for avoiding growth slumps around weaning.

\section{Housing, Bedding, and Automated Feeding Systems}

During this period, research showed that calves could be raised in groups without problems if they were fed greater amounts of milk or milk replacer (Costa et al., 2016). Automated milk feeders were shown to be especially useful in making gradual changes in milk intake (Jensen, 2006; Borderas et al., 2009; de Passillé et al., 2011), which makes management of feeding larger amounts of milk much easier.

\section{Behavior and Welfare}

The late 1990s saw the emergence of behavioral research as an accepted discipline, led by groups at the University of British Columbia and the Danish Institute of Agricultural Sciences, among others. These groups developed and carefully validated various methods to quantify effects of treatments on animal well-being.

Chua et al. (2002) found that calves raised in pairs grew faster and ate more starter than calves fed individually and displayed more evidence of well-being. Other area that have been explored include bedding comfort (Camiloti et al., 2012), mixing (O'Driscoll et al., 2006), and competition (Jensen et al., 2008).

The effect of various management procedures such as dehorning (Faulkner and Weary, 2000) and castration (Stewart et al., 2010) on pain and calf welfare became an important topic of research during this period. In addition, surveys of public opinion of aspects of dairy production have provided avenues for future management research (Ventura et al., 2013).

\section{Effects of Improved Early Nutrition on Subsequent Milk Production}

A research report by Bar-Peled et al. (1997) indicated that heifer calves allowed to suckle their dam during early life tended to produce more milk in later life. This finding created interest in potential effects of earlylife nutrition on later milk production. Soberon et al. (2012) used data from 2 herds to reveal a relationship between preweaning growth rate and subsequent milk production, which they attributed to the effect of nutrient intake above maintenance. Preweaning growth rate explained $22 \%$ of the variance in first-lactation milk yields. Soberon and Van Amburgh (2013) conducted a meta-analysis of 12 data sets that reported early-life intake and growth rates as well as first-lactation milk production. The model showed a highly significant effect of early nutrient intake on first-lactation milk yield $(+435 \mathrm{~kg})$ and an odds ratio of 2.09 , indicating that calves fed more milk or milk replacer in early life were 2 times more likely to have a greater milk yield in first lactation. Gelsinger et al. (2015) conducted a metaanalysis of preweaning diet and growth rate on firstlactation milk production. Their analysis also found that calves that grew more rapidly produced more milk. Brown et al. (2005) reported that heifers that were fed to grow more rapidly during the milk feeding period had greater mammary parenchymal development. In contrast, Kiezebrink et al. (2015) conducted a controlled study in which calves were fed either 4 or 8 $\mathrm{L}$ of whole milk and managed similarly from there on. No difference was found between the 2 treatments for first-lactation milk production.

\section{Maternal and Epigenetic Effects on Calves}

A new area of research in calves that emerged during the period from 1997 on was the effects of maternal 
environment and nutrition on calf health, growth, and future productivity. From a mechanistic standpoint, the field of epigenetics seems likely to explain many of these phenomena. For example, differences in maternal intake of trace minerals resulted in different phenotypic and physiologic responses in calves (Jacometo et al., 2015).

A major maternal environmental factor affecting calves is heat stress. Several studies during this period documented various aspects of calf growth and productivity that were negatively affected by maternal heat stress, which were reviewed by Tao and Dahl (2013). A recent series of studies by Monteiro et al. (2016a,b) showed that calves born to heat-stressed dams had lower birth BW, ate less starter, grew more slowly as calves, and produced less milk in first lactation. Genomic selection tools (Weigel et al., 2012) promise to have a major effect on selection of calves with only high genetic merit.

\section{FUTURE PROSPECTS FOR CALF NUTRITION AND MANAGEMENT}

As genomics identifies calves of superior genetic merit, nutrition and management will intensify and be more targeted to these calves to optimize their growth and development via the science of epigenetics. Marrying behavior with nutrition and management will further allow calves to be more comfortable and thrive better. Calf comfort will become as important as cow comfort is to cows. Management schemes and housing will increasingly take into account all of these factors and will evolve to allow improvement in calf performance. Feeding and management of calves will be done to incorporate knowledge of how to improve calf immunity. Methods to improve use of nonmilk protein in calf liquid diets will be developed. As herds get larger, calf feeding and management will become more attuned to best feeding and management practices and protocols.

\section{REFERENCES}

Abdelgadir, I. E. O., J. L. Morrill, J. A. Stutts, M. B. Morrill, D. E. Johnson, and K. C. Behnke. 1984. Effect of processing temperature on utilization of whole soybeans by calves. J. Dairy Sci. $67: 2554-2559$.

Akayezu, J. M., J. G. Linn, D. E. Otterby, W. P. Hansen, and D. G. Johnson. 1994. Evaluation of calf starters containing different amounts of crude protein for growth of Holstein calves. J. Dairy Sci. $77: 1882-1889$.

Alfaro, E., M. W. Neathery, W. J. Miller, C. T. Crowe, R. P. Gentry, A. S. Fielding, D. G. Pugh, and D. M. Blackmon. 1988. Influence of a wide range of calcium intakes on tissue distribution of macroelements and microelements in dairy calves. J. Dairy Sci. 71:1295-1300.

Appleman, R. D., and F. G. Owen. 1975. Breeding, housing, and feeding management. J. Dairy Sci. 58:447-464.
Arthington, J. D., M. B. Cattell, and J. D. Quigley III. 2000a. Effect of dietary IgG source (colostrum, serum, or milk-derived supplement) on the efficiency of Ig absorption in newborn Holstein calves. J. Dairy Sci. 83:1463-1467.

Arthington, J. D., M. B. Cattell, J. D. Quigley III, G. C. McCoy, and W. L. Hurley. 2000b. Passive immunoglobin transfer in newborn calves fed colostrum or spray-dried serum protein alone or as a supplement to colostrum of varying quality. J. Dairy Sci. $83: 2834-2838$

Atkeson, F. W., T. R. Warren, and G. C. Anderson. 1934. Water requirements of dairy calves. J. Dairy Sci. 17:249-256.

Bach, A., M. Terré, and A. Pinto. 2013. Performance and health responses of dairy calves offered different milk replacer allowances. J. Dairy Sci. 96:7790-7797.

Bar-Peled, U., B. Robinzon, E. Maltz, H. Tagari, Y. Folman, I. Bruckental, H. Voet, H. Gacitua, and A. R. Lehrer. 1997. Increased weight gain and effects on production parameters of Holstein heifer calves that were allowed to suckle from birth to six weeks of age. J. Dairy Sci. 80:2523-2528.

Barker, H. B., G. H. Wise, and N. L. Jacobson. 1952. Filled milks for dairy calves. III. Comparative value of various soybean oils and butter oil in a practical dietary regime. J. Dairy Sci. 35:507-514.

Bartlett, K. S., F. K. McKeith, M. J. VandeHaar, G. E. Dahl, and J. K. Drackley. 2006. Growth and body composition of dairy calves fed milk replacers containing different amounts of protein at two feeding rates. J. Anim. Sci. 84:1454-1467.

Bartley, E. E. 1973. Effects of a self-fed pelleted mixture of hay and calf starter on the performance of young dairy calves. J. Dairy Sci. $56: 817-820$.

Bascom, S. A., R. E. James, M. L. McGilliard, and M. Van Amburgh. 2007. Influence of dietary fat and protein on body composition of Jersey bull calves. J. Dairy Sci. 90:5600-5609.

Bate, W., D. Espe, and C. Y. Cannon. 1946. Influence of homogenization of fat on hair coat of dairy calves. J. Dairy Sci. 29:41-43.

Beiranvand, H., M. Khani, S. Omidian, M. Ariana, R. Rezvani, and M. H. Ghaffari. 2016. Does adding water to dry calf starter improve performance during summer? J. Dairy Sci. 99:1903-1911.

Berends, H., J. J. G. C. van den Borne, S. J. J. Alferink, C. G. van Reenen, E. A. M. Bokkers, and W. J. J. Gerrits. 2012. Low-protein solid feed improves the utilization of milk replacer for protein gain in veal calves. J. Dairy Sci. 95:6654-6664.

Berry, M. H. 1932. The use of skim milk powder in grain rations for dairy calves. J. Dairy Sci. 15:287-292.

Borderas, T. F., A. M. B. de Passillé, and J. Rushen. 2009. Feeding behavior of calves fed small or large amounts of milk. J. Dairy Sci. 92:2843-2852.

Bouchard, R., G. J. Brisson, and J. P. Julien. 1973. Nutritive value of bacterial sludge and whey powders for protein in calf milk replacers and on chromic oxide as indicator of digestibility. J. Dairy Sci. $56: 1445-1449$.

Boyd, L. J., and H. D. Hafs. 1965. Body size of calves from Holstein dams and sired by Holstein or Angus bulls. J. Dairy Sci. 48:1236-1240.

Brown, E. G., M. J. VandeHaar, K. M. Daniels, J. S. Liesman, L. T. Chapin, J. W. Forrest, R. M. Akers, R. E. Pearson, and M. S. W. Nielsen. 2005. Effect of increasing energy and protein intake on mammary development in Heifer calves. J. Dairy Sci. 88:595-603.

Brown, L. D., and C. A. Lassiter. 1962. Protein-energy ratios for dairy calves. J. Dairy Sci. 45:1353-1356.

Bryant, J. M., C. F. Foreman, N. L. Jacobson, and A. D. McGilliard. 1967. Protein and energy requirements of the young calf. J. Dairy Sci. 50:1645-1653.

Burkhalter, D. L., M. W. Neathery, W. J. Miller, R. H. Whitlock, J. C. Allen, and R. P. Gentry. 1980. Influence of a low chloride practical diet on acid-base balance and other factors of blood in young dairy calves. J. Dairy Sci. 63:269-276.

Bush, L. J., R. S. Allen, and N. L. Jacobson. 1959. Effect of chlortetracycline on nutrient utilization by dairy calves. J. Dairy Sci. 42:671-678.

Bush, L. J., and T. E. Staley. 1980. Absorption of colostral immunoglobulins in newborn calves. J. Dairy Sci. 63:672-680. 
Butler, J. A., S. A. Sickles, C. J. Johanns, and R. F. Rosenbusch. 2000. Pasteurization of discard mycoplasma mastitic milk used to feed calves: Thermal effects on various mycoplasma. J. Dairy Sci. 83:2285-2288.

Butler, J. E. 1969. Bovine immunoglobulins: A review. J. Dairy Sci. 52:1895-1909.

Caldwell, R. E. 1919. A further study of milk substitute materials in feeding dairy calves. J. Dairy Sci. 2:312-329.

Camiloti, T. V., J. A. Fregonesi, M. A. G. von Keyserlingk, and D. M. Weary. 2012. Short communication: Effects of bedding quality on the lying behavior of dairy calves. J. Dairy Sci. 95:3380-3383.

Campos, O. F., J. T. Huber, J. L. Morrill, R. K. Brownson, A. D. Dayton, H. J. S. Harrison, and R. G. Warner. 1982. Spray-dried fish solubles or soy protein concentrate in milk replacer formulations. J. Dairy Sci. 65:97-104.

Castells, L., A. Bach, G. Araujo, C. Montoro, and M. Terré. 2012. Effect of different forage sources on performance and feeding behavior of Holstein calves. J. Dairy Sci. 95:286-293.

Chua, B., E. Coenen, J. van Delen, and D. M. Weary. 2002. Effects of pair versus individual housing on the behavior and performance of dairy calves. J. Dairy Sci. 85:360-364.

Conrad, H. R., J. W. Hibbs, and N. Frank. 1958a. High roughage system for raising calves based on early development of rumen function. IX. Effect of rumen inoculations and chlortetracycline on rumen function of calves fed high roughage pellets. J. Dairy Sci. 41:1248-1261.

Conrad, H. R., J. W. Hibbs, W. D. Pounden, and T. S. Sutton. 1950. The effect of rumen inoculations on the digestibility of roughages in young dairy calves. J. Dairy Sci. 33:585-592.

Conrad, H. R., H. R. Smith, J. H. Vandersall, W. D. Pounden, and J. W. Hibbs. 1958b. Estimating gastrosplenic blood flow and volatile fatty acid absorption from the forestomachs of calves. J. Dairy Sci. 41:1094-1099.

Costa, J. H. C., M. A. G. von Keyserlingk, and D. M. Weary. 2016. Invited review: Effects of group housing of dairy calves on behavior, cognition, performance, and health. J. Dairy Sci. 99:2453-2467.

Coverdale, J. A., H. D. Tyler, J. D. Quigley III, and J. A. Brumm. 2004. Effect of various levels of forage and form of diet on rumen development and growth in calves. J. Dairy Sci. 87:2554-2562.

Crowe, N. A., M. W. Neathery, W. J. Miller, L. A. Muse, C. T. Crowe, J. L. Varnadoe, and D. M. Blackmon. 1990. Influence of high dietary aluminum on performance and phosphorus bioavailability in dairy calves. J. Dairy Sci. 73:808-818.

Davis, C. L., and J. K. Drackley. 1998. The Development, Nutrition, and Management of the Young Calf. Iowa State University Press, Ames.

de Passillé, A. M., T. F. Borderas, and J. Rushen. 2011. Weaning age of calves fed a high milk allowance by automated feeders: Effects on feed, water, and energy intake, behavioral signs of hunger, and weight gains. J. Dairy Sci. 94:1401-1408.

Depew, C. L., L. D. Bunting, J. M. Fernandez, D. L. Thompson Jr., and R. W. Adkinson. 1998. Performance and metabolic responses of young dairy calves fed diets supplemented with chromium tripicolinate. J. Dairy Sci. 81:2916-2923.

Diaz, M. C., M. E. Van Amburgh, J. M. Smith, J. M. Kelsey, and E. L. Hutten. 2001. Composition of growth of Holstein calves fed milk replacer from birth to 105-kilogram body weight. J. Dairy Sci. 84:830-842.

Donahue, M., S. M. Godden, R. Bey, S. Wells, J. M. Oakes, S. Sreevatsan, J. Stabel, and J. Fetrow. 2012. Heat treatment of colostrum on commercial dairy farms decreases colostrum microbial counts while maintaining colostrum immunoglobulin G concentrations. J. Dairy Sci. 95:2697-2702.

Drackley, J. K., R. M. Blome, K. S. Bartlett, and K. L. Bailey. 2006. Supplementation of $1 \%$ L-glutamine to milk replacer does not overcome the growth depression in calves caused by soy protein concentrate. J. Dairy Sci. 89:1688-1693.

Eckert, E., H. E. Brown, K. E. Leslie, T. J. DeVries, and M. A. Steele. 2015. Weaning age affects growth, feed intake, gastrointestinal development, and behavior in Holstein calves fed an elevated plane of nutrition during the preweaning stage. J. Dairy Sci. 98:6315-6326.
Eckles, C. H. 1919. A study of the birth weight of calves. J. Dairy Sci 2:159-169.

Elizondo-Salazar, J. A., and A. J. Heinrichs. 2009. Feeding heat-treated colostrum or unheated colostrum with two different bacterial concentrations to neonatal dairy calves. J. Dairy Sci. 92:4565-4571.

Esselburn, K. M., K. M. O'Diam, T. M. Hill, H. G. Bateman II, J. M. Aldrich, R. L. Schlotterbeck, and K. M. Daniels. 2013. Intake of specific fatty acids and fat alters growth, health, and titers following vaccination in dairy calves. J. Dairy Sci. 96:5826-5835.

Faulkner, P. M., and D. M. Weary. 2000. Reducing pain after dehorning in dairy calves. J. Dairy Sci. 83:2037-2041.

Fielding, A. S., W. J. Miller, M. W. Neathery, R. P. Gentry, and D. M. Blackmon. 1985. Effect of calcium and fat intake on calcium metabolism in calves. J. Dairy Sci. 68:2922-2928.

Fleenor, W. A., and G. H. Stott. 1980. Hydrometer test for estimation of immunoglobulin concentration in bovine colostrum. J. Dairy Sci. 63:973-977.

Foldager, J., J. T. Huber, and W. G. Bergen. 1977. Methionine and sulfur amino acid requirement in the preruminant calf. J. Dairy Sci. 60:1095-1104.

Foley, J. A., and D. E. Otterby. 1978. Availability, storage, treatment, composition, and feeding value of surplus colostrum: A review. J. Dairy Sci. 61:1033-1060.

Foote, W. D., W. J. Tyler, and L. E. Casida. 1959. Effect of some genetic and maternal environmental variations on birth weight and gestation length in Holstein cattle. J. Dairy Sci. 42:305-311.

Franklin, S. T., C. E. Sorenson, and D. C. Hammell. 1998. Influence of vitamin A supplementation in milk on growth, health, concentrations of vitamins in plasma, and immune parameters of calves. J. Dairy Sci. 81:2623-2632.

Gaudreau, J. M., and G. J. Brisson. 1980. Abomasum emptying in dairy calves fed milk replacers with varying fat and sources of protein. J. Dairy Sci. 63:426-440.

Gelsinger, S. L., A. J. Heinrichs, and C. M. Jones. 2016. A metaanalysis of the effects of preweaned calf nutrition and growth on first-lactation performance. J. Dairy Sci. 99:6206-6214.

Gelsinger, S. L., A. J. Heinrichs, C. M. Jones, R. J. Van Saun, D. R. Wolfgang, C. M. Burns, and H. R. Lysczek. 2014. Efficacy of onfarm use of ultraviolet light for inactivation of bacteria in milk for calves. J. Dairy Sci. 97:2990-2997.

Gelsinger, S. L., C. M. Jones, and A. J. Heinrichs. 2015. Effect of colostrum heat treatment and bacterial population on immunoglobulin G absorption and health of neonatal calves. J. Dairy Sci. 98:4640-4645.

Gengelbach, G. P., and J. W. Spears. 1998. Effects of dietary copper and molybdenum on copper status, cytokine production, and humoral immune response of calves. J. Dairy Sci. 81:3286-3292.

Gilliland, R. L., L. J. Bush, and J. D. Friend. 1962. Relation of ration composition to rumen development in early-weaned dairy calves with observations on ruminal parakeratosis. J. Dairy Sci. 45:1211-1217.

Godden, S. M., D. M. Haines, and D. Hagman. 2009. Improving passive transfer of immunoglobulins in calves. I: Dose effect of feeding a commercial colostrum replacer. J. Dairy Sci. 92:1750-1757.

Godden, S. M., S. Smith, J. M. Feirtag, L. R. Green, S. J. Wells, and J. P. Fetrow. 2003. Effect of on-farm commercial batch pasteurization of colostrum on colostrum and serum immunoglobulin concentrations in dairy calves. J. Dairy Sci. 86:1503-1512.

Godden, S. M., D. J. Smolenski, M. Donahue, J. M. Oakes, R. Bey, S. Wells, S. Sreevatsan, J. Stabel, and J. Fetrow. 2012. Heat-treated colostrum and reduced morbidity in preweaned dairy calves: Results of a randomized trial and examination of mechanisms of effectiveness. J. Dairy Sci. 95:4029-4040.

Groen, M. J., M. A. Steele, and T. J. DeVries. 2015. Short communication: Effect of straw inclusion rate in a dry total mixed ration on the behavior of weaned dairy calves. J. Dairy Sci. 98:2693-2700.

Guilloteau, P., M. Plodari, V. Romé, G. Savary, L. Le Normand, and R. Zabielski. 2011. Pancreatic enzyme deficiency depends on dietary protein origin in milk-fed calves. J. Dairy Sci. 94:1517-1525. 
Gullickson, T. W., F. C. Fountaine, and J. B. Fitch. 1942. Various oils and fats as substitutes for butterfat in the ration of young calves. J. Dairy Sci. 25:117-128.

Hammell, D. C., S. T. Franklin, and B. J. Nonnecke. 2000. Use of the relative dose response (RDR) assay to determine vitamin A status of calves at birth and four weeks of age. J. Dairy Sci. 83:1256-1263.

Hartman, D. A., R. W. Everett, S. T. Slack, and R. G. Warner. 1974. Calf mortality. J. Dairy Sci. 57:576-578.

Heinrichs, A. J., S. J. Wells, and W. C. Losinger. 1995. A study of the use of milk replacers for dairy calves in the United States. J. Dairy Sci. 78:2831-2837.

Hibbs, J. W., H. R. Conrad, and J. H. Vandersall. 1961. A highroughage system for raising calves based on the early development of rumen function. X. Whole blood, plasma, and corpuscle glucose relationships in calves fed high-roughage rations with and without chlortetracycline. J. Dairy Sci. 44:466-474.

Hill, T. M., H. G. Bateman II, J. M. Aldrich, and R. L. Schlotterbeck. 2010. Effect of milk replacer program on digestion of nutrients in dairy calves. J. Dairy Sci. 93:1105-1115.

Hill, T. M., H. G. Bateman II, J. M. Aldrich, R. L. Schlotterbeck, and K. G. Tanan. 2008. Optimal concentrations of lysine, methionine, and threonine in milk replacers for calves less than five weeks of age. J. Dairy Sci. 91:2433-2442.

Hill, T. M., M. J. VandeHaar, L. M. Sordillo, D. R. Catherman, H. G. Bateman II, and R. L. Schlotterbeck. 2011. Fatty acid intake alters growth and immunity in milk-fed calves. J. Dairy Sci. 94:39363948.

Hodson, H. H., A. D. McGilliard, N. L. Jacobson, and R. S. Allen. 1965. Metabolic role of rumen mucosa in absorption of butyrate. J. Dairy Sci. 48:1652-1656.

Hopkins, B. A., and J. D. Quigley III. 1997. Effects of method of colostrum feeding and colostrum supplementation on concentrations of immunoglobulin G in the serum of neonatal calves. J. Dairy Sci. 80:979-983.

Hopkins, D. T., R. G. Warner, and J. K. Loosli. 1959. Fat digestibility by dairy calves. J. Dairy Sci. 42:1815-1820.

Huber, J. T., S. Natrajan, and C. E. Polan. 1968. Varying levels of starch in calf milk replacers. J. Dairy Sci. 51:1081-1084

Huff, J. S., R. K. Waugh, and G. H. Wise. 1951. Effect of glycerolmono-stearate on fat absorption, growth and health of calves. J. Dairy Sci. 34:1056-1063.

Jacometo, C. B., J. S. Osorio, M. Socha, M. N. Corrêa, F. PiccioliCappelli, E. Trevisi, and J. J. Loor. 2015. Maternal consumption of organic trace minerals alters calf systemic and neutrophil mRNA and microRNA indicators of inflammation and oxidative stress. J. Dairy Sci. 98:7717-7729.

Jasper, J., and D. M. Weary. 2002. Effects of ad libitum milk intake on dairy calves. J. Dairy Sci. 85:3054-3058.

Jaster, E. H., G. C. McCoy, N. Spanski, and T. Tomkins. 1992. Effect of extra energy as fat or milk replacer solids in diets of young dairy calves on growth during cold weather. J. Dairy Sci. 75:2524-2531.

Jenkins, K. J., and M. Hidiroglou. 1986. Tolerance of the preruminant calf for selenium in milk replacer. J. Dairy Sci. 69:1865-1870.

Jenkins, K. J., and M. Hidiroglou. 1987. Effect of excess iron in milk replacer on calf performance. J. Dairy Sci. 70:2349-2354.

Jenkins, K. J., and M. Hidiroglou. 1989. Tolerance of the calf for excess copper in milk replacer. J. Dairy Sci. 72:150-156.

Jenkins, K. J., and M. Hidiroglou. 1990. Effects of elevated iodine in milk replacer on calf performance. J. Dairy Sci. 73:804-807.

Jenkins, K. J., and M. Hidiroglou. 1991. Tolerance of the preruminant calf for excess manganese or zinc in milk replacer. J. Dairy Sci. 74:1047-1053.

Jenkins, K. J., J. K. G. Kramer, and D. B. Emmons. 1986. Effect of lipids in milk replacers on calf performance and lipids in blood plasma, liver, and perirenal fat. J. Dairy Sci. 69:447-459.

Jenny, B. F., and G. D. O'Dell. 1981. Subsequent performance of calves held at near birth weight for the first three weeks of life. J. Dairy Sci. 64:1735-1737.

Jensen, M. B. 2006. Computer-controlled milk feeding of group-housed calves: The effect of milk allowance and weaning type. J. Dairy Sci. 89:201-206.
Jensen, M. B., A. M. de Passillé, M. A. G. von Keyserlingk, and J. Rushen. 2008. A barrier can reduce competition over teats in pairhoused milk-fed calves. J. Dairy Sci. 91:1607-1613.

Johnson, J. L., S. M. Godden, T. Molitor, T. Ames, and D. Hagman. 2007. Effects of feeding heat-treated colostrum on passive transfer of immune and nutritional parameters in neonatal dairy calves. J. Dairy Sci. 90:5189-5198.

Jones, C. M. 2006. One Hundred Years of Inquiry and Innovation. An Illustrated History of the American Dairy Science Association. American Dairy Science Association, Champaign, IL.

Kanjanapruthipong, J. 1998. Supplementation of milk replacers containing soy protein with threonine, methionine, and lysine in the diets of calves. J. Dairy Sci. 81:2912-2915.

Kastelic, J., O. G. Bentley, and P. H. Phillips. 1950. Studies on growth and survival of calves fed semi-synthetic milks from birth. J. Dairy Sci. 33:725-736.

Keener, H. A., G. P. Percival, K. S. Morrow, and G. H. Ellis. 1949. Cobalt tolerance in young dairy cattle. J. Dairy Sci. 32:527-533.

Kegley, E. B., J. W. Spears, and J. H. Eisemann. 1997. Performance and glucose metabolism in calves fed a chromium-nicotinic acid complex or chromium chloride. J. Dairy Sci. 80:1744-1750.

Kertz, A. F. 2007. Letter to the editor: Pelleted calf starter with straw access can confound results: A comment on Bach et al. (2007). J. Dairy Sci. 90:4924.

Kertz, A. F., and H. Chester-Jones. 2004. Invited review: Guidelines for measuring and reporting calf and heifer experimental data. J. Dairy Sci. 87:3577-3580.

Kertz, A. F., L. R. Prewitt, and J. P. Everett Jr. 1979. An early weaning calf program: Summarization and review. J. Dairy Sci. 62:1835-1843

Kertz, A. F., L. F. Reutzel, and J. H. Mahoney. 1984. Ad libitum water intake by neonatal calves and its relationship to calf starter intake, weight gain, feces score, and season. J. Dairy Sci. 67:2964-2969.

Kesler, E. M. 1962. Growth of Holstein calves on pasture from six to twenty weeks of age. J. Dairy Sci. 45:202-204.

Kesler, E. M. 1981. Feeding mastitic milk to calves: A review. J. Dairy Sci. 64:719-723.

Khan, M. A., H. J. Lee, W. S. Lee, H. S. Kim, S. B. Kim, K. S. Ki, S. J. Park, J. K. Ha, and Y. J. Choi. 2007. Starch source evaluation in calf starter: I. Feed consumption, body weight gain, structural growth, and blood metabolites in Holstein calves. J. Dairy Sci. 90:5259-5268.

Khan, M. A., D. M. Weary, and M. A. G. von Keyserlingk. 2011. Hay intake improves performance and rumen development of calves fed higher quantities of milk. J. Dairy Sci. 94:3547-3553.

Kiezebrink, D. J., A. M. Edwards, T. C. Wright, J. P. Cant, and V. R. Osborne. 2015. Effect of enhanced whole-milk feeding in calves on subsequent first-lactation performance. J. Dairy Sci. 98:349-356.

Kim, M. H., C. H. Yun, C. H. Lee, and J. K. Ha. 2012. The effects of fermented soybean meal on immunophysiological and stressrelated parameters in Holstein calves after weaning. J. Dairy Sci. 95:5203-5212.

Kincaid, R. L., B. P. Chew, and J. D. Cronrath. 1997. Zinc oxide and amino acids as sources of dietary zinc for calves: Effects on uptake and immunity. J. Dairy Sci. 80:1381-1388.

King, B. D., J. W. Lassiter, M. W. Neathery, W. J. Miller, and R. P. Gentry. 1980. Effect of a purified or corn-skim milk diet on retention and tissue distribution of manganese-54 in calves. J. Dairy Sci. 63:86-90

Klein, R. D., R. L. Kincaid, A. S. Hodgson, J. H. Harrison, J. K. Hillers, and J. D. Cronrath. 1987. Dietary fiber and early weaning on growth and rumen development of calves. J. Dairy Sci. 70:2095-2104.

Kuehn, C. S., D. E. Otterby, J. G. Linn, W. G. Olson, H. ChesterJones, G. D. Marx, and J. A. Barmore. 1994. The effect of dietary energy concentration on calf performance. J. Dairy Sci. 77:26212629 .

Labussiere, E., S. Dubois, J. van Milgen, G. Bertrand, and J. Noblet. 2008. Effects of dietary crude protein on protein and fat deposition in milk-fed veal calves. J. Dairy Sci. 91:4741-4754. 
Lammers, B. P., A. J. Heinrichs, and A. Aydin. 1998. The effect of whey protein concentrate or dried skim milk in milk replacer on calf performance and blood metabolites. J. Dairy Sci. 81:19401945.

Langford, F. M., D. M. Weary, and L. Fisher. 2003. Antibiotic resistance in gut bacteria from dairy calves: A dose response to the level of antibiotics fed in milk. J. Dairy Sci. 86:3963-3966.

Larson, L. L., F. G. Owen, J. L. Albright, R. D. Appleman, R. C Lamb, and L. D. Muller. 1977. Guidelines toward more uniformity in measuring and reporting calf experimental data. J. Dairy Sci. 60:989-991.

Lassiter, C. A., R. M. Grimes, and C. W. Duncan. 1958. Influence of antibiotics on the growth and protein metabolism of young dairy calves. J. Dairy Sci. 41:1417-1424.

Legault, C. R., and R. W. Touchberry. 1962. Heritability of birth weight and its relationship with production in dairy cattle. J. Dairy Sci. 45:1226-1233.

Lengemann, F. W., and N. N. Allen. 1955. The development of rumen function in the dairy calf I. Some characteristics of the rumen contents of cattle of various ages. J. Dairy Sci. 38:651-656.

Lengemann, F. W., and N. N. Allen. 1959. Development of rumen function in the dairy calf. II. Effect of diet upon characteristics of the rumen flora and fauna of young calves. J. Dairy Sci. 42:11711181.

Lesmeister, K. E., and A. J. Heinrichs. 2004. Effects of corn processing on growth characteristics, rumen development, and rumen parameters in neonatal dairy calves. J. Dairy Sci. 87:3439-3450.

Liang, Y., J. A. Carroll, and M. A. Ballou. 2016. The digestive system of 1-week-old Jersey calves is well suited to digest, absorb, and incorporate protein and energy into tissue growth even when calves are fed a high plane of milk replacer. J. Dairy Sci. 99:1929-1937.

Liang, Y. T., J. L. Morrill, and J. L. Noordsy. 1967. Absorption and utilization of volatile fatty acids by the young calf. J. Dairy Sci. 50:1153-1157.

Logner, K. R., M. W. Neathery, W. J. Miller, R. P. Gentry, D. M. Blackmon, and F. D. White. 1984. Lead toxicity and metabolism from lead sulfate fed to Holstein calves. J. Dairy Sci. 67:1007-1013.

Loosli, J. K., and H. D. Wallace. 1950. Influence of APF and aureomycin on the growth of dairy calves. Proc. Soc. Exp. Biol. Med. 75:531-533.

Luchini, N. D., S. F. Lane, and D. K. Combs. 1991. Evaluation of starter diet crude protein level and feeding regimen for calves weaned at 26 days of age. J. Dairy Sci. 74:3949-3955.

Luchini, N. D., S. F. Lane, and D. K. Combs. 1993. Preweaning intake and postweaning dietary energy effects on intake and metabolism of calves weaned at 26 days of age. J. Dairy Sci. 76:255-266.

Lundquist, N. S., and P. H. Phillips. 1943. Certain dietary factors essential for the growing calf. J. Dairy Sci. 26:1023-1030.

Macleod, G. K., E. B. Burnside, and D. G. Grieve. 1970. Growth of Holstein and Jersey calves in response to four feeding programs in a breed-by-ration interaction study. J. Dairy Sci. 53:1270-1274.

Malmuthuge, N., Y. Chen, G. Liang, L. A. Goonewardene, and L. L. Guan. 2015. Heat-treated colostrum feeding promotes beneficial bacteria colonization in the small intestine of neonatal calves. J. Dairy Sci. 98:8044-8053.

Martin, T. G., N. L. Jacobson, L. D. McGilliard, and P. G. Homeyer. 1962. Factors related to weight gain of dairy calves. J. Dairy Sci. $45: 886-892$.

Maynard, L. A., and L. C. Norris. 1923. A system of rearing dairy calves with limited use of milk. J. Dairy Sci. 6:483-499.

McCandlish, A. C. 1922a. Studies in the growth and nutrition of dairy calves. J. Dairy Sci. 5:301-320.

McCandlish, A. C. 1922b. Studies in the growth and nutrition of dairy calves: IV. The feed cost of growing dairy heifers. J. Dairy Sci. 5:348-361.

McCandlish, A. C. 1923a. Studies in the growth and nutrition of dairy calves: VII. The use of the self-feeder with young dairy calves. J. Dairy Sci. 6:500-508.

McCandlish, A. C. 1923b. Studies in the growth and nutrition of dairy calves: VIII. Raising dairy heifers by means of the self-feeder. J. Dairy Sci. 6:572-587.
McCandlish, A. C., and F. Ely. 1922. A metabolism crate for calves and other small ruminants. J. Dairy Sci. 5:565-569.

McCarthy, R. D., and E. M. Kesler. 1956. Relation between age of calf, blood glucose, blood and rumen levels of volatile fatty acids, and in vitro cellulose digestion. J. Dairy Sci. 39:1280-1287.

McMartin, S., S. Godden, L. Metzger, J. Feirtag, R. Bey, J. Stabel, S. Goyal, J. Fetrow, S. Wells, and H. Chester-Jones. 2006. Heat treatment of bovine colostrum. I: Effects of temperature on viscosity and immunoglobulin G level. J. Dairy Sci. 89:2110-2118.

Miller, W. J., R. P. Gentry, D. M. Blackmon, and H. H. Fosgate. 1991. Effects of high dietary iron as ferrous carbonate on performance of young dairy calves. J. Dairy Sci. 74:1963-1967.

Miller, W. J., M. W. Neathery, R. P. Gentry, D. M. Blackmon, C T. Crowe, G. O. Ware, and A. S. Fielding. 1987a. Bioavailability of phosphorus from defluorinated and dicalcium phosphates and phosphorus requirement of calves. J. Dairy Sci. 70:1885-1892.

Miller, W. J., P. E. Stake, M. W. Neathery, R. P. Gentry, and D. M. Blackmon. 1987b. Metabolism of manganese in calves as affected by dietary manganese and intravenous or duodenal manganese-54 dosing. J. Dairy Sci. 70:2085-2090.

Miller-Cushon, E. K., C. Montoro, A. Bach, and T. J. DeVries. 2013a. Effect of early exposure to mixed rations differing in forage particle size on feed sorting of dairy calves. J. Dairy Sci. 96:3257-3264.

Miller-Cushon, E. K., C. Montoro, A. Bach, and T. J. DeVries. 2013b. Effect of early exposure to mixed rations differing in forage particle size on feed sorting of dairy calves. J. Dairy Sci. 96:3257-3264.

Miller-Cushon, E. K., C. Montoro, I. R. Ipharraguerre, and A. Bach. 2014. Dietary preference in dairy calves for feed ingredients high in energy and protein. J. Dairy Sci. 97:1634-1644.

Mills, J. K., D. A. Ross, and M. E. Van Amburgh. 2010. The effects of feeding medium-chain triglycerides on the growth, insulin responsiveness, and body composition of Holstein calves from birth to 85 $\mathrm{kg}$ of body weight. J. Dairy Sci. 93:4262-4273.

Montagne, L., R. Toullec, M. Formal, and J. P. Lallès. 2000. Influence of dietary protein level and origin on the flow of mucin along the small intestine of the preruminant calf. J. Dairy Sci. 83:2820-2828.

Monteiro, A. P. A., J. R. Guo, X. S. Weng, B. M. Ahmed, M. J. Hayen, G. E. Dahl, J. K. Bernard, and S. Tao. 2016a. Effect of maternal heat stress during the dry period on growth and metabolism of calves. J. Dairy Sci. 99:3896-3907.

Monteiro, A. P. A., S. Tao, I. M. T. Thompson, and G. E. Dahl. 2016b. In utero heat stress decreases calf survival and performance through the first lactation. J. Dairy Sci. 99:8443-8450.

Morin, D. E., G. C. McCoy, and W. L. Hurley. 1997. Effects of quality, quantity, and timing of colostrum feeding and addition of a dried colostrum supplement on immunoglobulin $\mathrm{G}$ absorption in Holstein bull calves. J. Dairy Sci. 80:747-753.

Morrill, J. L., and S. L. Melton. 1973. Protein required in starters for calves fed milk once or twice daily. J. Dairy Sci. 56:927-931.

Morrill, J. L., J. M. Morrill, A. M. Feyerherm, and J. F. Laster. 1995. Plasma proteins and a probiotic as ingredients in milk replacer. J. Dairy Sci. 78:902-907.

Murley, W. R., N. L. Jacobson, and R. S. Allen. 1952. The effect of aureomycin supplementation on growth and feed utilization of young dairy calves. J. Dairy Sci. 35:846-856.

Neathery, M. W., D. G. Pugh, W. J. Miller, R. P. Gentry, and R. H. Whitlock. 1980. Effects of sources and amounts of potassium on feed palatability and on potassium toxicity in dairy calves. J. Dairy Sci. 63:82-85.

Nevens, W. B. 1919. The self-feeder for dairy calves. J. Dairy Sci $2: 435-443$

Noller, C. H., I. A. Dickson, and D. L. Hill. 1962. Value of hay and rumen inoculation in an early-weaning system for dairy calves. J. Dairy Sci. 45:197-201.

Nonnecke, B. J., R. L. Horst, W. R. Waters, P. Dubeski, and J. A Harp. 1999. Modulation of fat-soluble vitamin concentrations and blood mononuclear leukocyte populations in milk replacer-fed calves by dietary vitamin A and $\beta$-carotene. J. Dairy Sci. 82:26322641.

NRC (National Research Council). 2001. Nutrient Requirements of Dairy Cattle. 7th rev. ed. Natl. Acad. Press, Washington, DC. 
O'Driscoll, K., M. A. G. von Keyserlingk, and D. M. Weary. 2006. Effects of mixing on drinking and competitive behavior of dairy calves. J. Dairy Sci. 89:229-233.

Olson, K. E. 2016. 2015 dairy statistics and trends. DairyBusiness and HolsteinWorld June:9.

Ontsouka, E. C., C. Albrecht, and R. M. Bruckmaier. 2016. Invited review: Growth-promoting effects of colostrum in calves based on interaction with intestinal cell surface receptors and receptor-like transporters. J. Dairy Sci. 99:4111-4123.

Otterby, D. E., and J. G. Linn. 1981. Advances in nutrition and management of calves and heifers. J. Dairy Sci. 64:1365-1377.

Parrish, D. B., G. H. Wise, J. S. Hughes, and F. W. Atkeson. 1950. Properties of the colostrum of the dairy cow. V. Yield, specific gravity and concentrations of total solids and its various components of colostrum and early milk. J. Dairy Sci. 33:457-465.

Petit, H. V., M. Ivan, and G. J. Brisson. 1989. Digestibility measured by fecal and ileal collection in preruminant calves fed a clotting or a nonclotting milk replacer. J. Dairy Sci. 72:123-128.

Pounden, W. D., and J. W. Hibbs. 1948a. The influence of the ration and rumen inoculation on the establishment of certain microorganisms in the rumens of young calves. J. Dairy Sci. 31:1041-1050.

Pounden, W. D., and J. W. Hibbs. 1948b. The influence of the ratio of grain to hay in the ration of dairy calves on certain rumen microorganisms. J. Dairy Sci. 31:1051-1054.

Priestley, D., J. H. Bittar, L. Ibarbia, C. A. Risco, and K. N. Galvão. 2013. Effect of feeding maternal colostrum or plasma-derived or colostrum-derived colostrum replacer on passive transfer of immunity, health, and performance of preweaning heifer calves. J. Dairy Sci. 96:3247-3256.

Quigley, J. D., III, and J. K. Bernard. 1996. Milk replacers with or without animal plasma for dairy calves. J. Dairy Sci. 79:1881-1884.

Quigley, J. D., R. E. Strohbehn, C. J. Kost, and M. M. O'Brien. 2001. Formulation of colostrum supplements, colostrum replacers and acquisition of passive immunity in neonatal calves. J. Dairy Sci. 84:2059-2065.

Quillian, E. R., W. J. Miller, R. P. Gentry, S. R. Heinmiller, and M. W. Neathery. 1980. Maximum safe dietary magnesium and effects of high dietary magnesium on zinc metabolism in Holstein calves. J. Dairy Sci. 63:457-463.

Reddy, P. G., J. L. Morrill, and R. A. Frey. 1987. Vitamin E requirement of dairy calves. J. Dairy Sci. 70:123-129.

Reddy, P. V., J. L. Morrill, and L. S. Bates. 1993. Effect of roasting temperatures on soybean utilization by young dairy calves. J. Dairy Sci. 76:1387-1393.

Rusoff, L. L., A. V. Davis, and J. A. Alford. 1951. Growth-promoting effect of aureomycin on young calves weaned from milk at an early age. J. Nutr. 45:289-300.

Sander, E. G., R. G. Warner, H. N. Harrison, and J. K. Loosli. 1959 The stimulatory effect of sodium butyrate and sodium propionate on the development of rumen mucosa in the young calf. J. Dairy Sci. 42:1600-1605

Scibilia, L. S., L. D. Muller, R. S. Kensinger, T. F. Sweeney, and P. R. Shellenberger. 1987. Effect of environmental temperature and dietary fat on growth and physiological responses of newborn calves. J. Dairy Sci. 70:1426-1433.

Seegraber, F. J., and J. L. Morrill. 1982. Effect of soy protein on calves' intestinal absorptive ability and morphology determined by scanning electron microscopy. J. Dairy Sci. 65:1962-1970.

Silva, A. G., J. T. Huber, T. H. Herdt, R. Holland, R. M. Degregorio, and T. P. Mullaney. 1986. Morphological alterations of small intestinal epithelium of calves caused by feeding soybean protein. J. Dairy Sci. 69:1387-1393.

Silva, A. L., M. I. Marcondes, E. Detmann, F. S. Machado, S. C Valadares Filho, A. S. Trece, and J. Dijkstra. 2015. Effects of raw milk and starter feed on intake and body composition of Holstein $\times$ Gyr male calves up to 64 days of age. J. Dairy Sci. 98:2641-2649.

Soberon, F., E. Raffrenato, R. W. Everett, and M. E. Van Amburgh. 2012. Preweaning milk replacer intake and effects on long-term productivity of dairy calves. J. Dairy Sci. 95:783-793.

Soberon, F., and M. E. Van Amburgh. 2013. Lactation Biology Symposium: The effect of nutrient intake from milk or milk replacer of preweaned dairy calves on lactation milk yield as adults: A metaanalysis of current data. J. Anim. Sci. 91:706-712.

Stabel, J. R. 2001. On-farm batch pasteurization destroys Mycobacterium paratuberculosis in waste milk. J. Dairy Sci. 84:524-527.

Stewart, J., and J. W. McCallum. 1938. The vitamin A content of the colostrum of dairy cows. J. Agric. Sci. 28:428-436.

Stewart, J., and J. W. McCallum. 1942. The effect of a vitamin rich diet on the vitamin A content of the colostrum of dairy cows. J. Dairy Res. 13:1-4.

Stewart, M., G. A. Verkerk, K. J. Stafford, A. L. Schaefer, and J. R. Webster. 2010. Noninvasive assessment of autonomic activity for evaluation of pain in calves, using surgical castration as a model. J. Dairy Sci. 93:3602-3609.

Stewart, S., S. Godden, R. Bey, P. Rapnicki, J. Fetrow, R. Farnsworth M. Scanlon, Y. Arnold, L. Clow, K. Mueller, and C. Ferrouillet. 2005. Preventing bacterial contamination and proliferation during the harvest, storage, and feeding of fresh bovine colostrum. J. Dairy Sci. 88:2571-2578.

Stott, G. H., D. B. Marx, B. E. Menefee, and G. T. Nightengale. 1979a. Colostral immunoglobulin transfer in calves I. Period of absorption. J. Dairy Sci. 62:1632-1638.

Stott, G. H., D. B. Marx, B. E. Menefee, and G. T. Nightengale. 1979b. Colostral immunoglobulin transfer in calves II. The rate of absorption. J. Dairy Sci. 62:1766-1773.

Stott, G. H., D. B. Marx, B. E. Menefee, and G. T. Nightengale. 1979c. Colostral immunoglobulin transfer in calves III. Amount of absorption. J. Dairy Sci. 62:1902-1907.

Stott, G. H., D. B. Marx, B. E. Menefee, and G. T. Nightengale. 1979d. Colostral immunoglobulin transfer in calves IV. Effect of suckling. J. Dairy Sci. 62:1908-1913.

Suárez, B. J., C. G. Van Reenen, G. Beldman, J. van Delen, J. Dijkstra, and W. J. J. Gerrits. 2006. Effects of supplementing concentrates differing in carbohydrate composition in veal calf diets: I. Animal performance and rumen fermentation characteristics. J. Dairy Sci. 89:4365-4375

Suarez-Mena, F. X., A. J. Heinrichs, C. M. Jones, T. M. Hill, and J. D. Quigley. 2015. Digestive development in neonatal dairy calves with either whole or ground oats in the calf starter. J. Dairy Sci. 98:3417-3431

Suarez-Mena, F. X., A. J. Heinrichs, C. M. Jones, T. M. Hill, and J. D. Quigley. 2016. Straw particle size in calf starters: Effects on digestive system development and rumen fermentation. J. Dairy Sci. 99:341-353

Swan, H., S. Godden, R. Bey, S. Wells, J. Fetrow, and H. ChesterJones. 2007. Passive transfer of immunoglobulin $\mathrm{G}$ and preweaning health in Holstein calves fed a commercial colostrum replacer. J. Dairy Sci. 90:3857-3866.

Swanson, E. W., and J. D. Harris Jr. 1958. Development of rumination in the young calf. J. Dairy Sci. 41:1768-1776.

Swanson, E. W., J. E. Thigpen, J. Huskey, and B. P. Hazlewood. 1969. Comparative nutritional value of liquid milk and dried milk for young calves. J. Dairy Sci. 52:228-234.

Swanson, K. S., N. R. Merchen, J. W. Erdman Jr., J. K. Drackley, F. Orias, D. E. Morin, and M. F. Haddad. 2000. Influence of dietary vitamin A content on serum and liver vitamin A concentrations and health in preruminant Holstein calves fed milk replacer. J. Dairy Sci. 83:2027-2036.

Sweeney, B. C., J. Rushen, D. M. Weary, and A. M. de Passillé. 2010. Duration of weaning, starter intake, and weight gain of dairy calves fed large amounts of milk. J. Dairy Sci. 93:148-152.

Tamate, H., A. D. McGilliard, N. L. Jacobson, and R. Getty. 1962. Effect of various dietaries on the anatomical development of the stomach in the calf. J. Dairy Sci. 45:408-420.

Tao, S., and G. E. Dahl. 2013. Invited review: Heat stress effects during late gestation on dry cows and their calves. J. Dairy Sci. 96:4079-4093.

Terosky, T. L., A. J. Heinrichs, and L. L. Wilson. 1997. A comparison of milk protein sources in diets of calves up to eight weeks of age. J. Dairy Sci. 80:2977-2983. 
Tikofsky, J. N., M. E. Van Amburgh, and D. A. Ross. 2001. Effect of varying carbohydrate and fat content of milk replacer on body composition of Holstein bull calves. J. Anim. Sci. 79:2260-2267.

Traub, D. A., and E. M. Kesler. 1972. Effect of dietary protein-energy ratios on digestion and growth of Holstein calves at ages 8 to 18 weeks, and on free amino acids in blood. J. Dairy Sci. 55:348-352.

Tzeng, D., and C. L. Davis. 1980. Amino acid nutrition of the young calf. Estimation of methionine and lysine requirements. J. Dairy Sci. 63:441-450.

USDA. 2002. Part II: Changes in the United States dairy industry, 1991-2002. USDA Center for Epidemiology and Animal Health, National Animal Health Monitoring System, Fort Collins, CO.

USDA. 2016. Dairy data. Accessed Feb. 21, 2017. https://www.ers usda.gov/data-products/dairy-data/.

Ventura, B. A., M. A. G. von Keyserlingk, C. A. Schuppli, and D. M. Weary. 2013. Views on contentious practices in dairy farming: The case of early cow-calf separation. J. Dairy Sci. 96:6105-6116.

Walker, W. L., W. B. Epperson, T. E. Wittum, L. K. Lord, P. J. Rajala-Schultz, and J. Lakritz. 2012. Characteristics of dairy calf ranches: Morbidity, mortality, antibiotic use practices, and biosecurity and biocontainment practices. J. Dairy Sci. 95:2204-2214.

Warner, R. G., W. P. Flatt, and J. K. Loosli. 1956. Dietary factors influencing the development of the ruminant stomach. J. Agric. Food Chem. 4:788-792.

Webb, L. E., C. G. van Reenen, H. Berends, B. Engel, I. J. M. de Boer, W. J. J. Gerrits, and E. A. M. Bokkers. 2015. The role of solid feed amount and composition and of milk replacer supply in veal calf welfare. J. Dairy Sci. 98:5467-5481.

Weigel, K. A., P. C. Hoffman, W. Herring, and T. J. Lawlor Jr.. 2012. Potential gains in lifetime net merit from genomic testing of cows, heifers, and calves on commercial dairy farms. J. Dairy Sci. $95: 2215-2225$.

Wiese, A. C., B. C. Johnson, H. H. Mitchell, and W. B. Nevens. 1947. Synthetic rations for the dairy calf. J. Dairy Sci. 30:87-94.

Willett, L. B., J. L. Albright, and M. D. Cunningham. 1969. Onceversus twice-daily feeding of milk replacer to calves. J. Dairy Sci. $52: 390-391$

Williams, J. B., and C. B. Knodt. 1949. The value of milk replacements in the rations of dairy calves. J. Dairy Sci. 32:986-992.

Williams, J. B., and C. B. Knodt. 1950. The further development of milk replacements for dairy calves. J. Dairy Sci. 33:809-814.

Wright, C. L., and J. W. Spears. 2004. Effect of zinc source and dietary level on zinc metabolism in Holstein calves. J. Dairy Sci. 87:1085-1091.

Xu, C., T. Wensing, and A. C. Beynen. 1997. The effects of dietary soybean versus skim milk protein on plasma and hepatic concentrations of zinc in veal calves. J. Dairy Sci. 80:2156-2161.

$\mathrm{Xu}, \mathrm{C} ., \mathrm{T}$. Wensing, and A. C. Beynen. 1998. Effects of high calcium intake on fat digestion and bile acid excretion in feces of veal calves. J. Dairy Sci. 81:2173-2177. 


\section{APPENDIX}

Table A1. Milestones in the past $100 \mathrm{yr}$ of calf nutrition and management

\begin{tabular}{|c|c|}
\hline Date & Milestone \\
\hline 1919 & $\begin{array}{l}\text { The first calf article is published in the Journal of Dairy Science evaluating factors influencing } \\
\text { birth weight of calves. }\end{array}$ \\
\hline 1919 & Nonmilk ingredient sources for liquid diets are evaluated. \\
\hline 1923 & Early weaning at 1 mo to conserve whole-milk feeding and utilize starter ration \\
\hline 1934 & Water intake is measured with 30 heifers from birth to 24 mo of age. \\
\hline $1937-1956$ & A total of 77 papers are published on minerals and vitamins, particularly vitamin $A$. \\
\hline $1947-1951$ & Colostrum composition is measured. \\
\hline $1948-1956$ & $\begin{array}{l}\text { Initial calf rumen development studies, including role of VFA from rumen fermentation, are } \\
\text { performed. }\end{array}$ \\
\hline $1950 \mathrm{~s}$ & Antibiotic feeding for growth and performance \\
\hline $1958-1960$ & Antibiotic feeding and performance \\
\hline 1969 & Calf immunity review \\
\hline 1970s-mid 1980s & Colostrum collection, feeding, and preservation \\
\hline 1975 & Calf feeding, management, and housing review \\
\hline 1977 & Standard procedures for conducting calf trials and reporting data \\
\hline 1977 and 1980 & Met requirements in milk replacers \\
\hline 1979 & Early calf weaning program review \\
\hline 1980s and 1990s & Nonmilk protein sources, abomasal clotting, and antinutritional factors are evaluated. \\
\hline
\end{tabular}


Table A1 (Continued). Milestones in the past $100 \mathrm{yr}$ of calf nutrition and management

\begin{tabular}{|c|c|}
\hline 1980-1987 & Macromineral requirements \\
\hline 1981 & 25 -yr summary of calf nutrition and management \\
\hline 1984 & Effect of water intake on calf performance is established. \\
\hline 1987 and 1992 & Cold weather requirements and fat supplementation \\
\hline 1987 & Vitamin E requirements \\
\hline Late 1990s-early 2000s & Studies on trace minerals and some fat-soluble vitamins show efficacy and interrelationships. \\
\hline Early 2000 s & $\begin{array}{l}\text { Milk replacers change from skim and } C N \text { to whey proteins and some nonmilk protein sources } \\
\text { along with some } A A \text { and fatty acid supplementation. }\end{array}$ \\
\hline 2000-2001 & Conditions to heat-treat waste milk for enteric pathogenic organism control \\
\hline $2001-2006$ & $\begin{array}{l}\text { Studies establish growth and body composition when calves are fed more and higher protein } \\
\text { milk replacers. }\end{array}$ \\
\hline $2012-2015$ & Forage provision for calves fed pelleted starters \\
\hline $2013-2015$ & Palatability of starter ingredients and feeding behavior \\
\hline 2014-2016 & Negative effects of maternal heat stress on subsequent calf growth and milk production \\
\hline
\end{tabular}

